\title{
Caracterização faciológica e evolução sedimentar da Formação Moeda (Supergrupo Minas) na porção noroeste do Quadrilátero Ferrífero, Minas Gerais
} Faciologic characterization and sedimentary evolution of Moeda Formation
(Minas Supergroup) in Northwestern Quadrilátero Ferrifero, Minas Gerais

\author{
Mariana de Resende Madeira ${ }^{1}$ (D), Maximiliano de Souza Martins ${ }^{1}$ (i), \\ Gustavo Pereira Martins ${ }^{1}$ (D), Fernando Flecha Alkmim¹ (iD \\ 1 Universidade Federal de Ouro Preto - UFOP, Escola de Minas, Departamento de Geologia - EM/DEGEO, Campus Morro do \\ Cruzeiro, s/n., Bauxita, CEP 35400-000, Ouro Preto, MG, BR (marirmadeira@gmail.com; maximilianomartins@yahoo.com.br; \\ martins.mgeo@gmail.com; alkmim@degeo.ufop.br; ffalkmim@gmail.com)
}

Recebido em 26 de julho de 2018; aceito em 29 de maio de 2019

\begin{abstract}
Resumo
A Formação Moeda, ao longo da região noroeste do Quadrilátero Ferrífero, registra os primeiros estágios da Bacia Minas, desenvolvida no limite Neoarqueano/Paleoproterozoico no sul do Cráton do São Francisco (CSF). Este trabalho analisa essa unidade a partir de seis perfis estratigráficos de detalhe nos quais foram identificadas nove fácies sedimentares: quatro conglomeráticas (Gms, Gm, Gt e Gp), três essencialmente areníticas (St, Sp e Sh) e duas predominantemente pelíticas (F1 e Fsc). As seções estratigráficas foram correlacionadas, possibilitando o agrupamento das fácies em cinco associações geneticamente relacionadas. As associações de fácies AF1 e AF2 representam sistemas de leques aluviais que evoluíram para planícies fluviais entrelaçadas. AF3 está relacionada a um sistema lacustre associado a marinho raso nas porções distais. Por fim, as associações de fácies AF4 e AF5 representam planícies fluviais entrelaçadas encerradas por uma transgressão marinha no estágio final de evolução da bacia. Com o auxílio do mapeamento geológico-estrutural de detalhe dessas associações e da confecção de uma seção restaurada foi possível interpretar que as AF1, AF2, AF3 e a porção basal da AF4 foram depositadas durante os estágios iniciais do rifteamento continental, e as demais associações materializam a transição rifte-margem passiva.
\end{abstract}

Palavras-chave: Formação Moeda; Paleoproterozoico; Associação de fácies; Rifte; Margem passiva.

\begin{abstract}
The Moeda Formation, along the northwestern region of the Quadrilátero Ferrífero, registers the first stages of the Minas basin, during the Neoarchean/Paleoproterozoic, south of the São Francisco Craton. This paper examines this unit from six stratigraphic sections where nine sedimentary facies were characterized: four conglomerate facies (Gms, Gm, Gt and Gp), three sandstones ( $\mathrm{St}, \mathrm{Sp}$ and $\mathrm{Sh}$ ) and two predominant mudstones (Fl and Fsc). The stratigraphic sections were correlated allowing the grouping of the facies in five genetically related associations. The associations of facies AF1 and AF2 presents an alluvial fan system which evolved into interlaced fluvial plains. AF3 is related to a shallow marine associated lake system in the distal portions. Finally, the association of facies AF4 and AF5 represent interlaced fluvial plains enclosed by a marine transgression in the final evolution stage of the basin. Based on the geological-structural detail mapping of these facies associations and in a restored section, it is interpreted that AF1, AF2, AF3, and the basal portion of AF4 were deposited during the initial stages of the continental rift, and the other associations materialize the transition between the stages rift and passive margin.
\end{abstract}

Keywords: Moeda Formation; Paleoproterozoic; Facies associations; Rift; Passive margin. 


\section{INTRODUÇÃO}

A Formação Moeda (Wallace, 1958; Dorr, 1969), constituída de um pacote de 60 a $1.000 \mathrm{~m}$ de espessura de meta-arenitos, metaconglomerados e metapelitos, forma a base do Supergrupo Minas na província mineral do Quadrilátero Ferrífero (QF), em Minas Gerais. Depositada na passagem entre o Neoarqueano e Paleoproterozoico (Lana et al., 2013; Dopico et al., 2017), a Formação Moeda é interpretada como registro do evento de rifteamento que precedeu o desenvolvimento da bacia de margem passiva que viria a ser preenchida pelas formações marinhas Batatal, Cauê e Gandarela que lhe sucedem no Supergrupo Minas (Alkmim e Martins-Neto, 2012). Essa interpretação é fundamentada nas descrições existentes sobre a constituição geral e a natureza da sucessão litológica da Formação Moeda (Wallace, 1958; Dorr, 1969; Pires, 1979; Villaça, 1981; Renger et al., 1993; Renger et al., 1994; Canuto, 2010), não existindo, porém, estudos de detalhe que propiciem uma visão geral do arcabouço faciológico e que explorem o significado da unidade em termos paleogeográficos e tectônicos.

Tendo como objetivo preencher essa lacuna do conhecimento, o presente trabalho reúne os resultados de uma investigação sedimentológica e estratigráfica de detalhe realizada na localidade tipo da Formação Moeda, a serra homônima, localizada na porção noroeste do QF. Após a caracterização do cenário geológico em que se insere a unidade em foco e a apresentação da metodologia empregada no presente estudo, passa-se, nas seções seguintes, à descrição de fácies, unidades de fácies e sua distribuição espacial. Conclui-se com um modelo deposicional-paleogeográfico, o qual encerra uma contribuição ao conhecimento das condições gerais de instalação da Bacia Minas na virada das eras neoarqueana e paleoproterozoica.

\section{CONTEXTO GEOLÓGICO E ESTUDOS PRÉVIOS DA FORMAÇÃO MOEDA}

O QF está localizado no extremo sul do Cráton do São Francisco (CSF) e constitui, com o Cinturão Mineiro, exposições do orógeno paleoproterozoico nessa unidade cratônica (Teixeira et al., 2000). No CSF, esses terrenos paleoproterozoicos estão expostos em uma complexa associação com unidades arqueanas e bordejados por cinturões neoproterozoicos (Alkmim e Marshak, 1998; Alkmim et al., 2006; Figura 1).

Além de unidades constitutivas do embasamento arqueano, representadas por complexos de granitoides e TTG de idades compreendidas entre 3220 e $2580 \mathrm{Ma}$, e da sucessão greenstones belts do Supergrupo Rio das Velhas, datada entre 2930 e $2760 \mathrm{Ma}$ (Romano et al., 2013; Lana et al., 2013; Farina et al., 2016), encontram-se expostas no QF as sequências metassedimentares do Supergrupo Minas e do Grupo Itacolomi (Figura 1).

O Supergrupo Minas é constituído por rochas metassedimentares de origem química e clástica (Figura 2) cuja idade é neoarqueana e paleoproterozoica (Babinski et al., 1995; Renger et al., 1994; Hartmann et al., 2006; Cabral et al., 2012; Koglin et al., 2014).

Segundo Alkmim e Martins-Neto (2012), o Supergrupo Minas abrange duas sequências separadas por uma discordância regional. A sequência basal envolve rochas provenientes de ambientes continentais e marinhos (Dorr et al., 1957; Dorr, 1969; Renger et al., 1994). Compreende o Grupo Caraça, onde está inserida a Formação Moeda, abordada neste trabalho, sucedida pela Formação Batatal, essencialmente pelítica. O Grupo Itabira, sobreposto geralmente de maneira brusca e localmente gradual, é constituído principalmente por formações ferríferas bandadas (itabiritos - Formação Cauê) e rochas carbonáticas (Formação Gandarela). Encerrando a sequência basal do Supergrupo Minas têm-se meta-arenitos alternados por metapelitos que definem o Grupo Piracicaba (Dorr, 1969). O Grupo Caraça representa a fase rifte e de transição para margem passiva na Bacia Minas. O Grupo Itabira marca uma grande transgressão, representando o período de máxima inundação da bacia (Alkmim e Marshak, 1998; Alkmim e Martins-Neto, 2012). O Grupo Piracicaba é associado a um ambiente marinho-deltaico (Dorr, 1969).

O Grupo Sabará define a sequência superior do Supergrupo Minas. Essencialmente turbidítico com contribuições químicas, é relacionado à deposição sin-orogênica do evento do Riaciano/Orosiriano (Alkmim e Marshak, 1998). O Grupo Itacolomi representa uma unidade à parte entre as sequências supracrustais do QF (Figura 2) constituída de meta-arenitos sericíticos, metaconglomerados polimíticos e filitos (Dorr, 1969). Essa unidade é interpretada como um depósito acumulado durante o colapso extensional ao final da orogenia Riaciana/Orosiriana (Alkmim e Martins-Neto, 2012).

Segundo Wallace (1958) e Dorr (1969), a Formação Moeda, na sua área tipo, estrada que liga a BR-040 ao Distrito Moeda, localizado na serra homônima, tem espessura aproximada de $600 \mathrm{~m}$ e é constituída essencialmente de metaconglomerados, quartzitos grosseiros a finos e filitos laminados que podem ser subdivididos em três unidades informais. Diversos estudos tanto na Serra da Moeda quanto em outras regiões indicam que a ocorrência dessas unidades informais e a proporção dos litotipos na constituição da Formação Moeda variam ao longo da sua ocorrência em todo o QF (Pires, 1979; Villaça, 1981; Renger et al., 1993; Renger et al., 1994; Canuto, 2010; Nunes, 2016; Dopico et al., 2017). O contato basal é, normalmente, em discordância angular com as unidades sotopostas, Supergrupo Rio das Velhas e Complexos Metamórficos. Nesta superfície ocorrem localmente zonas cisalhamento de várias 
naturezas (Rynearson et al., 1954; Pires, 1979; Nalini Jr., 1990; Endo e Nalini Jr., 1992). O contato de topo com a Formação Batatal é definido por uma superfície de conformidade gradacional (Canuto, 2010) e, localmente, abrupta (Dorr, 1969; Pires, 1979).

Nas décadas de 1970 e 80, a Formação Moeda foi alvo de uma campanha de exploração mineral para urânio. A litoestratigrafia revelada pelos testemunhos de sondagem foi compilada por Villaça (1981), que descreveu três membros informais (Figura 2). O membro 1, com espessura da ordem de $180 \mathrm{~m}$, inicia-se com uma sequência de metaconglomerados texturalmente muito imaturos. A sua matriz é predominantemente sericítica, geralmente piritosa e mais raramente carbonosa. Em direção ao topo gradam para quartzitos grosseiros a médios com estratificação cruzada acanalada. O membro 2, com $70 \mathrm{~m}$, é formado por um pacote de filitos com interlaminações milimétricas de quartzito muito fino e metasiltitos. O membro 3 apresenta, na base, corpos lenticulares de metaconglomerado polimítico e, de maneira geral, quartzitos médios a finos, gradando em direção ao topo para quartzitos predominantemente finos. Tem espessura aproximada de $100 \mathrm{~m}$. A unidade basal,

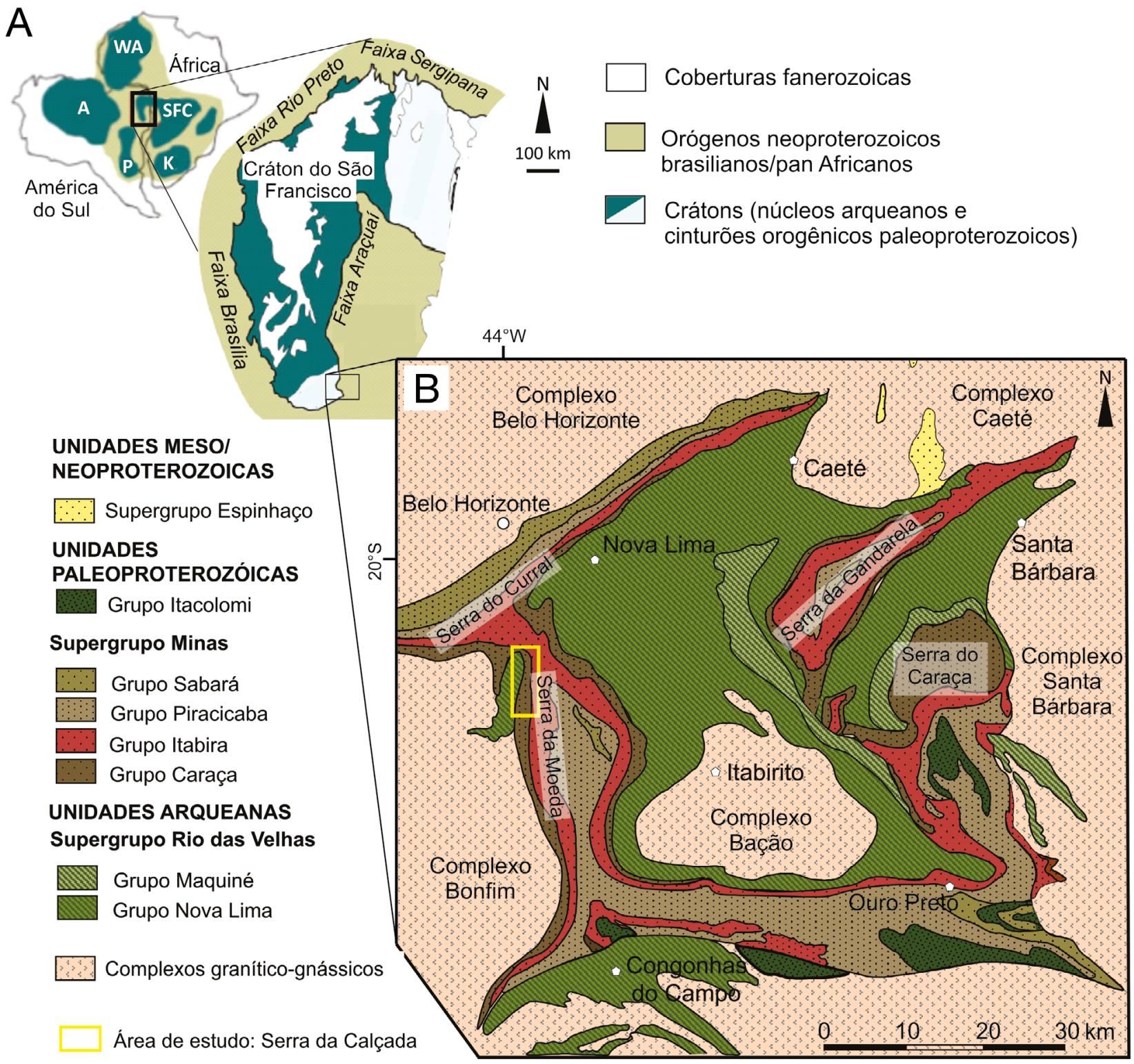

A: Amazônico; P: Rio de la Plata; WA: Oeste Africano; SFC: São Francisco/Congo; K: Kalahari.

Fonte: modificado de Renger et al. (1994); Alkmim e Marshak (1998).

Figura 1. (A) O cráton do São Francisco no cenário geotectônico do Gondwana ocidental. Crátons da América do Sul e África; (B) esboço geológico das unidades litoestratigráficas do Quadrilátero Ferrífero. 
segundo o mesmo autor, registraria um sistema aluvial/fluvial entrelaçado, com ocorrências/mineralizações de ouro e urânio; a unidade intermediária representaria um afogamento de parte do membro 1 por uma transgressão marinha; e a unidade superior marcaria o retorno de um regime aluvial/fluvial entrelaçado, com discreta contribuição marinha em direção ao topo.

Pires (1979) sugere que a relação espessura da unidade (Formação Moeda) versus espessura da camada de conglomerado pode indicar variações no regime de fluxo, características do relevo, ou proximidade da área fonte. Villaça (1981) observou, na porção norte da Serra da Moeda, a diminuição gradativa dos conglomerados em direção ao sul, até seu completo desaparecimento. À medida que esses níveis diminuem e ficam mais delgados, a Formação Moeda tornar-se-ia mais espessa, predominando meta-arenitos com maior grau de maturidade textural. Esse autor sugere que durante a deposição da formação Moeda nessa região atuaram 2 ou 3 direções de paleodrenagem, uma de $\mathrm{N}$ para $\mathrm{S}$, outra de $\mathrm{E}$ para SW e a terceira de W para S. A primeira paleodrenagem seria responsável pela conformação de extensos leques de conglomerados e arenitos grosseiros, enquanto as outras duas convergiam para o mar.

Renger et al. (1994) propõem o início da implementação da Protobacia Minas sobre uma plataforma arqueana recém-consolidada. Essa bacia, segundo esse autor, seria alimentada pela erosão dos domos gnáissicos adjacentes - em processo de soerguimento - além das unidades do Supergrupo Rio das Velhas (Noce et al., 1992), sustentando altos estruturais proporcionados por escarpas de falhas (Renger et al., 1993).

Aplicando o método de estratigrafia de sequências na Formação Moeda na Serra do Caraça, Canuto (2010) apresenta para essa unidade duas sequências de $3^{\mathrm{a}}$ ordem. Esse autor considera que, na transição Moeda/Batatal, ocorre evolução tectônica na qual a plataforma estável com posterior rifteamento se desenvolve para bacia de margem continental passiva.

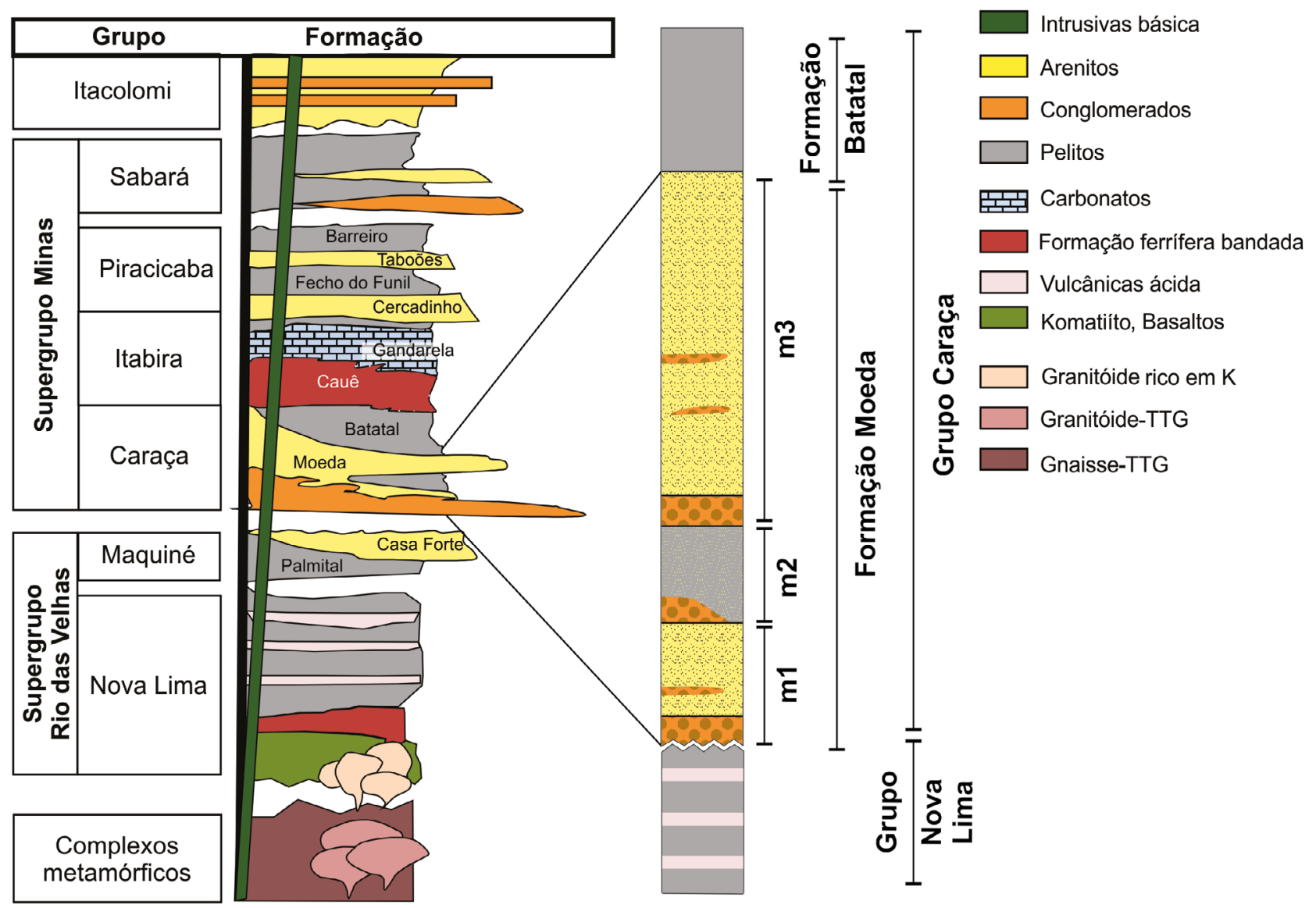

Fonte: adaptado de Villaça (1981) e Koglin et al. (2014).

Figura 2. Coluna estratigráfica do Quadrilátero Ferrífero. Modificado de Dorr (1969), Alkmim e Marshak (1998), e Farina et al. (2016). Destaque para a coluna litoestratigráfica esquemática da Formação Moeda - (m1) membro 1; (m2) membro 2; (m3) membro 3. 
Os primeiros dados geocronológicos disponíveis para a Formação Moeda indicam que a sua deposição e, consequentemente, a do Supergrupo Minas tiveram início após 2600 Ma (Machado et al., 1996). Hartmann et al. (2006), em um segundo estudo dos zircões detríticos da unidade, advogam que a sua idade máxima seria $2580 \pm 7$ Ma; e a mínima, de $2420 \mathrm{Ma}$, seria dada pela idade $\mathrm{Pb}-\mathrm{Pb}$ relacionada à diagênese dos carbonatos estromatolíticos da Formação Gandarela, posicionada acima da Formação Moeda (Babinski et al., 1995). No entanto, Cabral et al. (2012) obtiveram idades $\mathrm{U}-\mathrm{Pb}$ de $2650 \mathrm{Ma}$ em uma suposta camada metavulcânica que ocorre intercalada na Formação Cauê, o que implicaria em uma idade arqueana, controversa, para os estágios iniciais da Bacia Minas. Recentemente, trabalhando nos mesmos níveis individualizados por Villaça (1981), Dopico et al. (2017) obtiveram idades máximas de deposição para a Formação Moeda de 2680 Ma para a base (membro 1), de e 2610 Ma para o topo (membro 3). Para esses autores, a Formação Moeda estaria limitada no intervalo entre 2600 e $2420 \mathrm{Ma}$. Na Serra do Caraça, localizada no extremo leste do QF, Nunes (2016) apresenta idade deposicional máxima de $2520 \pm 13$ Ma para o Grupo Tamanduá correlativo da Formação Moeda.

\section{METODOLOGIA}

A Formação Moeda ocupa a maior parte das escarpas íngremes que configuram os principais acidentes geográficos da região (Dorr, 1969). Localizada na porção ocidental do QF, a Serra da Moeda é uma feição morfoestrutural de direção meridiana, com escarpamento expressivo ao oeste, em que os pacotes rochosos apresentam mergulhos para leste com orientação preferencial 094/46.

A área investigada situa-se na porção norte da Serra da Moeda, conhecida localmente como Serra da Calçada, está aproximadamente a $17 \mathrm{~km}$ da capital estadual, Belo Horizonte. Buscando compreender os estágios inicias de implementação da Bacia Minas detalhando o arcabouço faciológico da Formação Moeda, essa região foi escolhida para a investigação por conter os registros estratigráficos proximais do ponto de vista sedimentológico e pela proximidade da área-tipo dessa unidade (Villaça, 1981; Renger et al., 1993; Renger et al., 1994; Canuto 2010).

A caracterização das fácies e a sua posterior associação foram fundamentadas em levantamentos sedimentológicos e mapeamento geológico em escala 1:10.000. Seis seções estratigráficas de detalhe, escala 1:200, foram levantadas nas escarpas da Serra da Calçada (Figura 3). Os contatos de base e de topo com os xistos do Supergrupo Rio das Velhas e com os filitos da Formação Batatal, respectivamente, foram utilizados como datuns estratigráficos para o mapeamento geológico e para os levantamentos faciológicos.
Os levantamentos estratigráficos foram feitos utilizando o método com vara Jacob, orientados ao longo de seções transversais ao trend da Formação Moeda na área. Durante esse processo buscou-se definir as fácies sedimentares para uma análise sedimentológica e as futuras associações de fácies.

As descrições das rochas metassedimentares de baixo grau metamórfico foram feitas segundo as propostas dos manuais de campo de Tucker (2014) e Stow (2006) utilizando a nomenclatura de rochas sedimentares, suprimindo os termos metamórficos. Foram caracterizados os aspectos composicionais e texturais, as estruturas sedimentares, a geometria das camadas e as direções de paleocorrentes, quando possível, nos litotipos mapeados. Apesar da relativa recristalização dos grãos em função dos processos metamórficos, as relações texturais/granulométricas estão preservadas. O código de fácies aplicado neste estudo, assim como as interpretações das fácies e de suas associações, foram adaptados de Miall $(1977,1978,1996)$. A nomenclatura para os arenitos foi baseada nas porcentagens relativas, estimadas a olho nu, dos principais componentes da rocha, como proposto por Folk (1980) e Pettijohn et al. (1987).

Para a integrar e balizar das seções levantadas, após a identificação das litofácies, considerou-se a superfície de contato de topo com a Formação Batatal como um datum. Essa passagem, que ocorre de forma gradual e localmente abrupta, define a superfície de inundação/discordância mais relevante da área, refletindo mudança do aporte energético do ambiente ocasionada por uma transgressão marinha.

A partir da integração das seções levantadas, as litofácies descritas foram agrupadas em unidades mapeáveis ou associações de fácies classificadas e interpretadas baseando em critérios propostos por Walker e James (1992), Tucker (2014) e Miall (2016). As unidades mapeadas foram projetadas horizontalizando as camadas e, posteriormente, retirando os efeitos da deformação nesses litotipos. Nesse contexto, foi obtida uma seção esquemática NS restaurada, em que a principal referência foi a superfície de transgressão marinha representada pela Formação Batatal, datum estratigráfico de topo.

\section{LITOFÁCIES E ASSOCIAÇÕES DE LITOFÁCIES}

Na Serra da Calçada, a Formação Moeda tem espessuras que variam entre $195 \mathrm{~m}$, ao norte, e $442 \mathrm{~m}$, ao sul, e assenta-se em discordância angular sobre os xistos arqueanos do Supergrupo Rio das Velhas. É caracterizada por metaconglomerados basais líticos texturalmente imaturos de ocorrência restrita, que passam a meta-arenitos associados a metasiltitos, metapelitos e lentes de metaconglomerados. Em direção ao topo, os metarenitos tornam-se texturalmente bem selecionados e as intercalações com níveis ricos em sericita são mais frequentes. O contato com a Formação Batatal é transicional. 


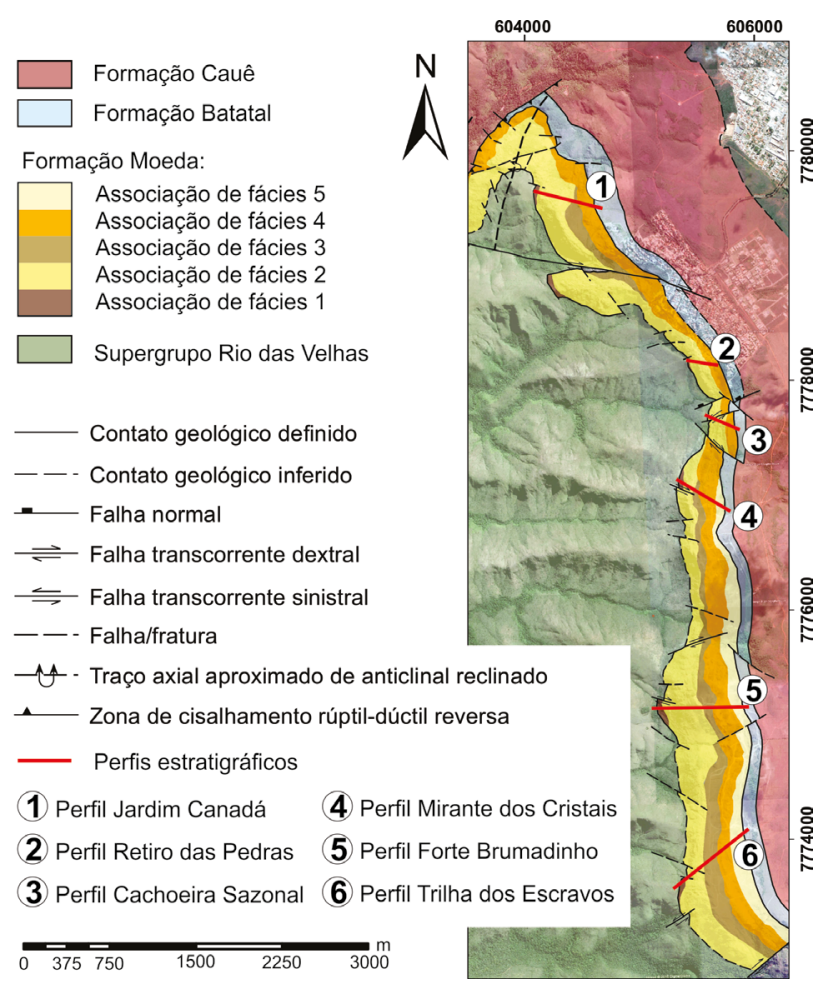

Figura 3. Mapa geológico da região do segmento norte da Serra da Moeda, conhecido como Serra da Calçada, mostrando as associações de fácies mapeadas e indicando os perfis estratigráficos feitos para levantamento dos dados sedimentológicos.

\section{Litofácies}

Com base em características composicionais, tamanho de grãos, estruturas sedimentares e geometria das camadas foi possível distinguir nove litofácies que, individualmente, representam processos deposicionais distintos (Tabela 1).

\section{Fácies Gms (conglomerado suportado pela matriz)}

Litofácies de ocorrência restrita à base das seções levantadas na Serra da Calçada, em que foram identificados seis afloramentos descontínuos de conglomerados polimíticos, maciços, suportados pela matriz. Ocorre em contato basal angular e erosivo sobre os xistos do Supergrupo Rio das Velhas. O contato de topo, quando observado, é gradual com as litofácies subsequentes. Lateralmente, os corpos são interrompidos por mudança faciológica e/ou zonas de falhas mapeadas e interpretadas a partir de lineamentos identificados em imagens de satélite e dados geofísicos.

As espessuras dos corpos conglomeráticos podem variar de 4 a 14 m, aproximadamente. Localmente, esses pacotes podem apresentar descontinuidades erosivas em seu interior. Pobremente a moderadamente selecionados, os clastos estão dispostos de maneira desordenada e não apresentam nenhuma estratificação (Figura 4A). A moda do diâmetro dos clastos fica em torno de $7 \mathrm{~cm}$, mas variam de 1 até $30 \mathrm{~cm}$, tendo esfericidade baixa a moderada e grau de arredondamento diversificado, muito angulosos a arredondados

Tabela 1. Litofácies da Formação Moeda com as principais estruturas sedimentares e as interpretações.

\begin{tabular}{|c|c|c|c|}
\hline Código & Litofácies & Estruturas sedimentares & Interpretação \\
\hline Gms & $\begin{array}{l}\text { Conglomerado suportado } \\
\text { por matriz argilosa }\end{array}$ & Gradação incipiente & Depósitos de fluxo de detritos \\
\hline $\mathrm{Gm}$ & $\begin{array}{c}\text { Conglomerado } \\
\text { grosseiramente acamadado } \\
\text { ou maciço }\end{array}$ & Acamamento horizontal & $\begin{array}{l}\text { Barras e formas de leito longitudinais, } \\
\text { depósitos residuais tipo lag, }\end{array}$ \\
\hline Gt & Conglomerado estratificado & Estratificações cruzadas acanaladas & Preenchimento de canais \\
\hline Gp & Conglomerado estratificado, & Estratificações cruzadas planares & Formas de leito transversais \\
\hline St & $\begin{array}{c}\text { Arenito médio a muito } \\
\text { grosso, as vezes com } \\
\text { clastos }\end{array}$ & Estratificações cruzadas acanaladas & $\begin{array}{l}\text { Dunas } 3 \mathrm{D} \text {, lingoides, depósitos } \\
\text { residuais tipo lag, }\end{array}$ \\
\hline Sp & $\begin{array}{l}\text { Arenito médio a muito } \\
\text { grosso, as vezes com } \\
\text { grânulos. }\end{array}$ & $\begin{array}{c}\text { Estratificações cruzadas planares e } \\
\text { laminações cruzadas de marcas onduladas }\end{array}$ & $\begin{array}{l}\text { Dunas 2D, marcas onduladas (regime } \\
\text { de fluxo inferior) }\end{array}$ \\
\hline Sh & Arenito fino a muito grosso & Estratificações horizontais a maciço & $\begin{array}{c}\text { Formas de leito planos (regime de fluxo } \\
\text { superior) }\end{array}$ \\
\hline $\mathrm{Fl}$ & $\begin{array}{l}\text { Arenitos finos, muito finos a } \\
\text { siltitos e pelitos intercalados }\end{array}$ & $\begin{array}{l}\text { Laminações finas, ripples muito } \\
\text { pequenas, estratificações cruzadas de } \\
\text { pequeno porte com baixo ângulo. }\end{array}$ & $\begin{array}{l}\text { Planície de inundação, overbank } \\
\text { deposits, dunas atenuadas. }\end{array}$ \\
\hline FsC & Siltitos e pelitos & Laminado ou maciço & $\begin{array}{l}\text { Depósitos de planície de inundação } \\
\text { ou fluxos de baixa energia, com } \\
\text { decantação de material em suspensão. }\end{array}$ \\
\hline
\end{tabular}

Fonte: adaptado de Miall (1996). 

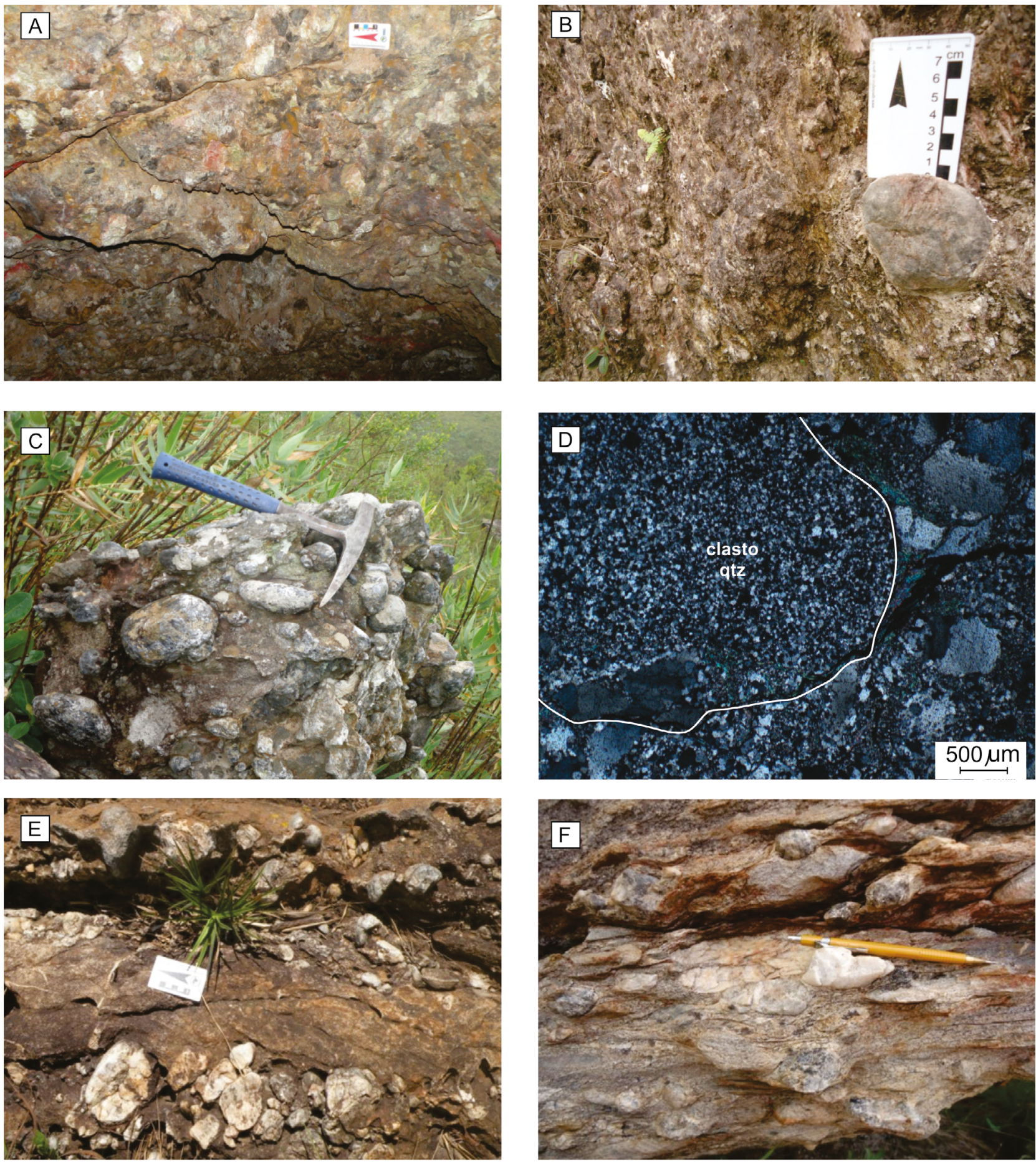

Figura 4. (A; B) Fácies Gms: conglomerado suportado por uma matriz argilosa com clastos de composição e tamanhos variados; (C) Fácies Gm: conglomerado suportado por uma matriz arenosa com clastos de distintos tamanhos e composição principalmente quartzosa; (D) Fácies Gm: fotomicrografia de conglomerado com matriz arenosa texturalmente mal selecionada e clasto de quartzito; (E) Fácies Gt: conglomerado com estratos cruzados acanalados e clastos imbricados; (F) Fácies Gp: conglomerado com acamamento e estratos cruzados planares. 
(Figura 4B). Quanto à composição, os clastos podem ser de quartzo de veio (cristalino, leitoso ou fumê), meta-arenito, metachert, gnaisse e metapelitos. A matriz varia de areia fina a pelítica, com cores variando de branco a avermelhado e cinza, geralmente com pirita. A natureza maciça e desorganizada e, principalmente, o fato de serem suportados pela matriz argilosa sugerem deposição por fluxos de detritos (Miall, 1996).

\section{Fácies Gm (conglomerado maciço a acamadado)}

Esta litofácies ocorre frequentemente em corpos que recobre aqueles da litofácies Gms e, mais esporadicamente, no topo dos perfis Jardim Canadá e Retiro das Pedras Pitangueiras. Raramente ocorre em camadas contínuas; é comumente encontrada em forma de lentes delgadas. Pode apresentar espessuras que variam de 1 a $25 \mathrm{~m}$. Os contatos basal e de topo podem ser erosivos ou gradacionais. Essa fácies ocorre destituída de estruturas internas ou com incipiente acamamento (Figura 4C).

Os clastos variam tanto em composição quanto no tamanho. Em geral, são de xistos, filitos, quartzos fumê, cristalino e leitoso, e quartzitos. Os diâmetros variam de 1 até $30 \mathrm{~cm}$. São subarrendados e a esfericidade é moderada (Figura 4C). A matriz é quartzosa e sericítica, e localmente tem pirita e óxidos. Os grãos são mal selecionados, variando de areia fina a grossa. Os processos envolvidos na sedimentação desta fácies podem ser característicos de barras e formas de leito longitudinais e depósitos residuais tipo lag. Este tipo de depósito pode estar associado também às porções distais de leques aluviais (Miall, 1996).

\section{Fácies Gt (conglomerado}

com estratos cruzados acanalados)

Os conglomerados com estratos cruzados acanalados (fácies Gt) foram observados restritos à porção central da Serra da Calçada, nos perfis Mirante dos Cristais e Forte Brumadinho. A fácies é constituída de corpos lenticulares de conglomerados polimíticos, frequentemente sustentadas pelos clastos e, localmente, pela matriz. Tem, em média, $4 \mathrm{~m}$ de espessura e é formada por níveis de conglomerado e arenito intercalados (Figura 4E) inseridos em meio a uma camada de siltito por contato erosivo.

Os clastos são moderadamente bem selecionados, com grau de esfericidade mediano e, geralmente, subarredondados, podendo chegar a $30 \mathrm{~cm}$. São compostos por quartzo de veios cristalino, leitoso, fumê e, em menor proporção, por quartzito e filito, com imbricamento incipiente (Figura 4E). A matriz essencialmente arenosa é mal selecionada, composta por quartzo e sericita. No interior dos corpos lenticulares ocorrem estratificações cruzadas acanaladas. A fácies é característica de preenchimento de pequenos canais (Miall, 1996).

\section{Fácies Gp (conglomerado} com estratos cruzados planares)

Esta litofácies consiste em conglomerados líticos e ocorre principalmente na porção sul da Serra da Calçada, em afloramentos com menor expressão nos perfis Mirante dos Cristais e Forte Brumadinho. Os corpos de conglomerado estão dispostos em lentes e geralmente têm contatos erosivos com as camadas de siltitos. As lentes, que variam de 3 a $16 \mathrm{~m}$, podem conter internamente intercalações centimétricas de arenitos mal selecionados (Figura 4F).

Os conglomerados sustentados pelos clastos são predominantes, e localmente ocorrem sustentados pela matriz. Os clastos chegam a $30 \mathrm{~cm}$ de diâmetro, são moderadamente arredondados a subangulosos, com grau de esfericidade médio. Em sua maioria, são constituídos das mesmas variedades de quartzo descritas nas fácies anteriores, ocorrendo também filitos e quartzitos. A matriz é imatura e arenosa, mal selecionada, com composição mineralógica de quartzo e, eventualmente, sericita, pirita e óxidos. Existe um acamamento incipiente definido por estratificações cruzadas planares (Figura 4F). As características apresentadas por esta litofácies sugerem formas de leito transversais e migração de barras longitudinais (Miall, 1996).

\section{Fácies St (arenito com granulação média a muito grossa com estratos cruzados acanalados)}

A litofácies St foi descrita nos perfis nas porções central e sul da serra da Calçada, não sendo observada nos perfis Jardim Canadá e Retiro das Pedras Pitangueiras. Essencialmente composta por arenitos com granulometria variando de areia média a grossa, tem laminações/estratificações cruzadas acanaladas de baixo ângulo (Figura 5A). Os sets podem variar de 5 a $80 \mathrm{~cm}$ e os pacotes desse litotipo chegam a $35 \mathrm{~m}$. Na maioria das seções estão sobrepostos e sotopostos aos arenitos com laminação horizontal a maciços (fácies Sh), em contato abrupto ou erosivo.

Quanto à composição mineralógica, são constituídos por grãos de quartzo cristalino, quartzo fumê, sericita e, em menor quantidade, feldspatos e carbonatos alterados. Afloram com colorações variando do branco amarelado ao cinza, dependendo da proporção dos grãos de quartzo fumê e do grau de alteração. Habitualmente, os grãos têm esfericidade moderada, são subarredondados, e os pacotes variam quanto ao grau de seleção granulométrica, mantendo, em geral, grãos com granulometria moderadamente selecionada.

Além de estratos cruzados acanalados ocorrem marcas onduladas lingoides centimétricas (Figura 5B) e níveis localizados de conglomerado com clastos milimétricos (Figura 5C). Esta fácies possivelmente representa um depósito tipo lag relacionado à migração de dunas 3D (Miall, 1996). 

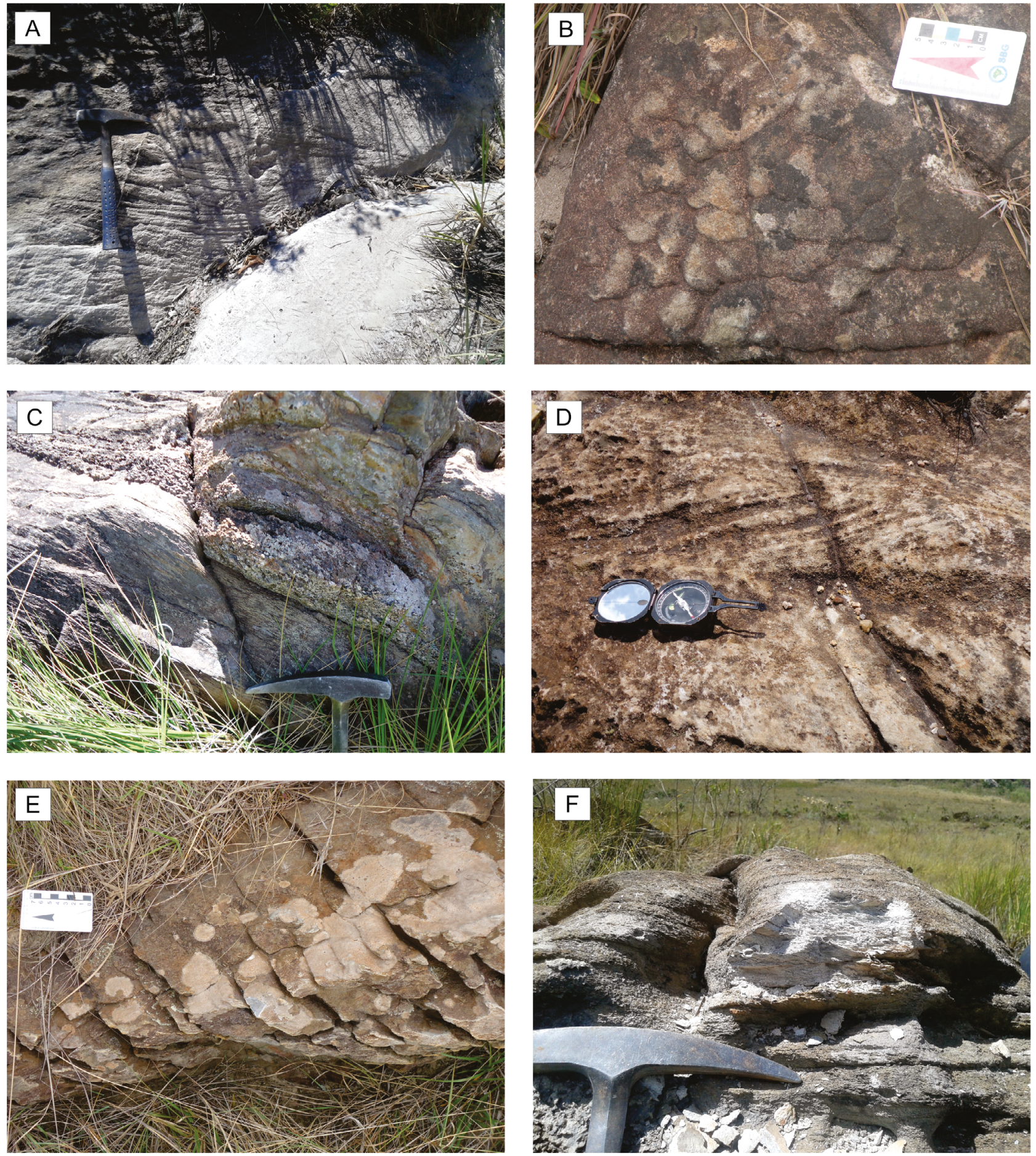

Figura 5. (A) Fácies St: estratos cruzados acanalados de pequeno porte em arenito de granulometria média moderadamente selecionado; (B) Fácies St: marcas onduladas lingoides; (C) Fácies St: estratos cruzados acanalados em arenito de granulação média a grossa com intercalações de níveis conglomeráticos com clastos milimétricos; (D) Fácies Sp: estratos cruzados tabulares em arenito de granulação média bem selecionado; (E) Fácies Sp: marcas de onduladas assimétricas com cristas paralelas em arenito de granulação grossa moderadamente selecionado; (F) Fácies Sh: arenito de granulação media a grossa, com acamamento plano incipiente. 
Fácies Sp (arenito com granulação média a muito grossa e estratos cruzados tabulares)

Esta litofácies ocorre de forma similar à litofácies St. Ambas foram descritas nas mesmas seções (porções central e sul da serra da Calçada) e são texturalmente muito semelhantes. É caracterizada por arenitos com laminações/estratificação cruzada tabular planar, ocorrendo também marcas onduladas assimétricas com cristas paralelas (Figuras 5D e 5E). Os sets variam de 3 a $50 \mathrm{~cm}$, separados localmente por superfícies erosivas. Os contatos de base e de topos dos pacotes são geralmente erosivos com as litofácies Sh.

Sua composição é essencialmente arenosa, ocorrendo raramente sericita derivada de argilo-minerais, pouco feldspato e carbonatos alterados. Os grãos são de quartzo fumê ou cristalino e variam de areia média a muito grossa, angulosos a subarredondados, com esfericidade intermediária. A coloração é diversificada de branco amarelada a avermelhada, dependendo da área de ocorrência. Tais características permitem interpretá-la como produto da migração subaquosa a jusante de dunas $2 \mathrm{D}$, em regime de fluxo inferior (Miall, 1996).

\section{Fácies Sh (arenito com laminação horizontal a maciço, granulação fina a muito grossa)}

A litofácies Sh é a de maior abrangência, ocorrendo em todas as seções levantadas e tendo maior expressão na porção norte da Serra da Calçada. As camadas, limitadas por contatos erosivos ou gradacionais, têm extensa continuidade lateral e podem chegar a $50 \mathrm{~m}$ de espessura. São compostas por estratos horizontais de 1 a $5 \mathrm{~cm}$ e níveis maciços ou que não tiveram as estruturas preservadas devido à deformação (Figura 5F).
Apresentam colorações avermelhadas, amareladas, esbranquiçadas e são geralmente mais acinzentadas quando ocorrem em pacotes de granulometria areia fina a média. Constituída essencialmente de grãos de quartzo cristalino ou fumê, com ocorrência subordinada de sericita, níveis de óxidos, carbonatos, feldspato e fragmentos líticos de quartzito e siltitos, a granulometria varia de areia fina a muito grossa, às vezes com grânulos. Apresenta baixo grau de maturidade textural, com grãos subangulosos a subarredondados e de esfericidade baixa a moderada (Figuras 6A e 6B). Esta litofácies representa formas de leito plano, interpretada como gerada em regime de fluxo superior (Miall, 1996).

\section{Fácies Fl (arenito a siltito com ripples)}

Esta litofácies está entre as texturalmente mais finas que afloram na área. Comumente encontrada no meio dos perfis estratigráficos, a fácies tem extensão lateral praticamente contínua na Serra da Calçada, onde só não foi descrita na seção Retiro das Pedras Pitangueiras. Em direção ao sul, esta litofácies torna-se mais espessa e com maior expressão areal. Os contatos com as fácies sotopostas são, na maioria das vezes, abruptos, e com as subsequentes, gradacionais.

A fácies Fl é composta por siltito e arenito de granulação areia fina, muito fina, a silte, podendo ocorrer níveis pelíticos em intercalações milimétricas (Figuras 7A e 7B). A composição mineralógica é variada, formada por grãos de quartzo cristalino e fumê, micas, argilominerais, carbonatos e óxidos de ferro. Tem tons acinzentados quando predominam as areias finas; nos níveis mais siltosos, assume colorações ocres a terrosas; e, nos pelíticos, coloração esverdeada ou acinzentada escura. As variações granulométricas são comuns, apresentando grau de seleção intermediário, com grãos subarredondados e com esfericidade moderada.
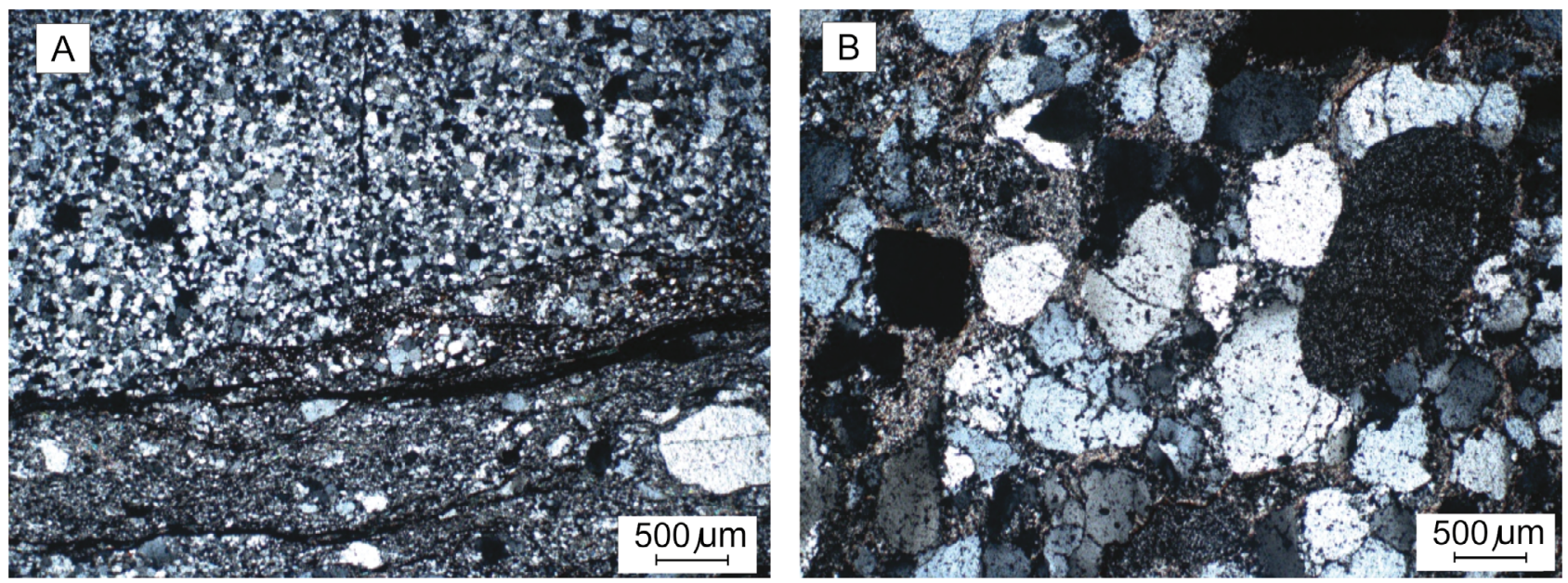

Figura 6. Fácies Sh: (A) fotomicrografia de arenito acamadado com nível basal mal selecionado com granulometria fina a grossa e, no topo arenito bem selecionado com granulometria média; (B) fotomicrografia de arenito com grãos subangulosos a subarredondados e esfericidade moderada. 
Esta fácies ocorre em pacotes acamadados a maciços, com estruturas sedimentares menos frequentes. Nos níveis siltosos a pelíticos, ocorrem localmente laminações paralelas, marcas de ondulações de pequeno porte e, mais raramente, acamamento lenticular (Figura 7A). Nas porções em que as camadas pelíticas dominam, as delgadas lentes de areias podem indicar variações no suprimento sedimentar ou no nível de atividade das correntes, características comuns em planícies de marés e em sedimentos de frente deltaica (Tucker, 2014). Porém, o caráter arenoso a siltoso predominante leva à interpretação, também, de depósitos externos ao canal fluvial, canais abandonados ou depósitos de planície de inundação (Miall, 1996).

\section{Fácies Fsc (siltito a pelito laminados ou maciço)}

A litofácies Fsc consiste em pelitos que apresentam coloração variando de acinzentado escuro a claro e arroxeado
(Figura 7C). Na Serra da Calçada, esses pelitos podem ocorrer localmente em lentes descontínuas próximas às fácies rudíticas posicionadas na base da Formação Moeda. Sua expressão em área e nos perfis é mais proeminente em direção ao topo das colunas, na transição para a Formação Batatal. O contato com as outras fácies é gradacional. Esta litofácies tem porções ricas em material carbonoso e é essencialmente composta de sericita (derivada de argilominerais) e pouco ou nenhum conteúdo em quartzo (Figura 7D). Duas interpretações podem ser atribuídas a esta litofácies:

- relacionada aos depósitos de planície de inundação;

- a fluxos de baixa energia, com decantação de material em suspensão (Miall, 1996).

\section{Associações de litofácies}

Nos trabalhos de campo, mas especialmente a partir da integração das seções levantadas, verificou-se que as nove
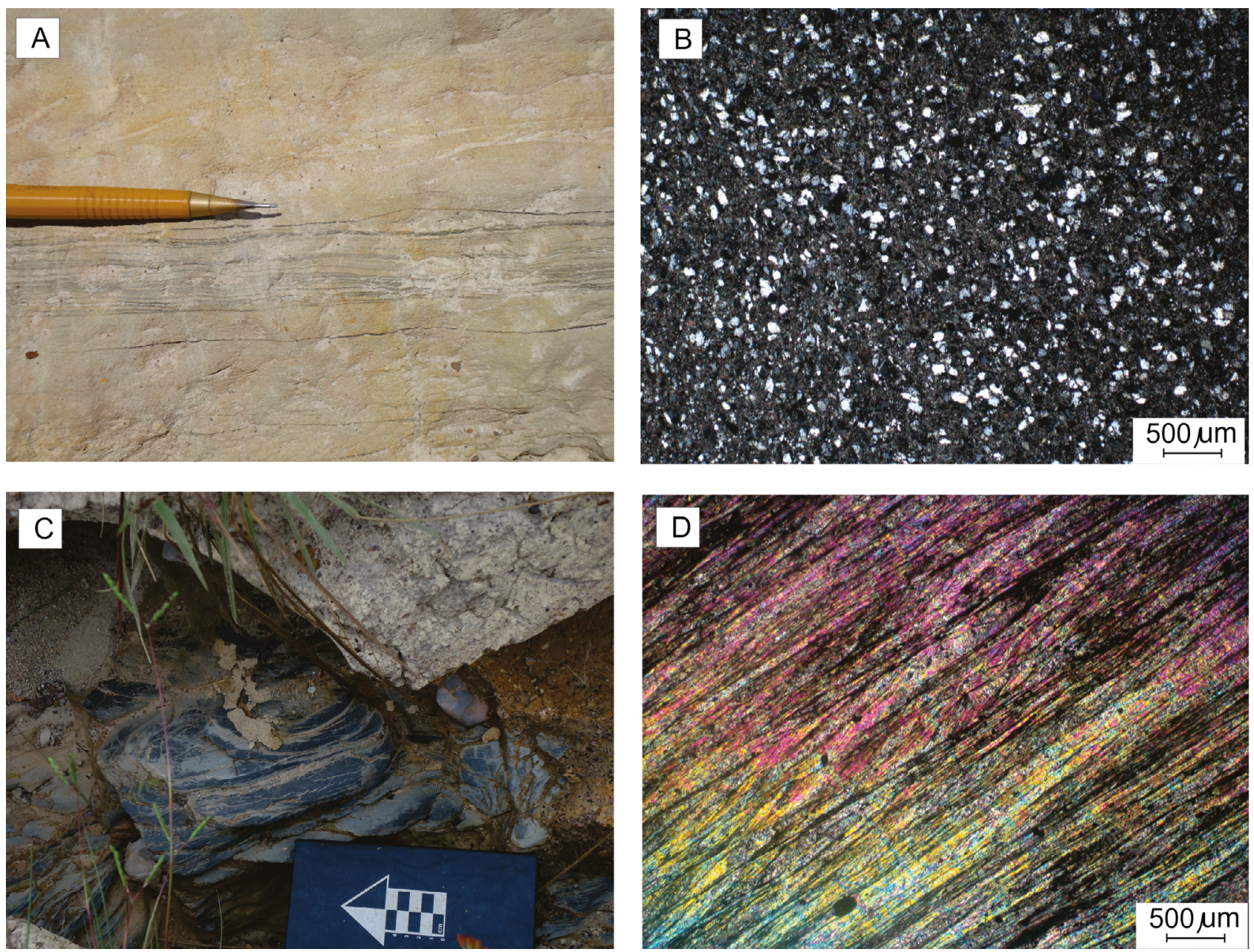

Figura 7. (A) Fácies Fl: siltito com níveis pelíticos carbonosos milimétricos com ondulações; (B) Fácies Fl: fotomicrografia de siltito; (C) Fácies Fsc: pelito carbonoso intercalado a arenito fino; (D) Fotomicrografia de pelito carbonoso: metamorfisado composto essencialmente de sericita. 
litofácies descritas definem conjuntos espacialmente relacionados e, por essa razão, foram agrupadas em cinco unidades mapeáveis ou associações de fácies denominadas AF1, AF2, AF3, AF4 e AF5 (Tabela 2; Figura 8).

\section{Associação de fácies 1 (AF1): sistema de leques aluviais com rios entrelaçados associados}

A AF1 é a de menor ocorrência areal e constitui os litotipos basais da Formação Moeda (Figura 3). Tem espessuras variáveis de 4 a 18 m e não foi reconhecida na porção centro-norte da área estudada (Figura 8).

Esta associação de fácies é imatura do ponto de vista textural e composicional. Composta de conglomerados polimíticos, com matriz argilosa e clastos mal selecionados, é constituída essencialmente pelas litofácies Gms e Gm, e localmente pela Fsc. Os clastos são arredondados a angulosos, com tamanhos de até $30 \mathrm{~cm}$, constituídos por quartzo de veio, filitos, xistos, quartzito, metachert e, mais raramente, gnaisse. Estes estão suportados por uma matriz argilosa, fácies Gms, característica textural diagnóstica da base dessa AF. No topo, em contato abrupto e localmente gradacional, ocorrem conglomerados de matriz arenosa, com presença de pirita, fácies $\mathrm{Gm}$. Nesta fácies, os clastos são mal selecionados e menores, apresentado gradação normal incipiente. Recobrindo essa associação, raramente, ocorrem lâminas de material pelítico extremamente fino e carbonoso, fácies Fsc que podem chegar a $2 \mathrm{~m}$ de espessura e $20 \mathrm{~m}$ de extensão lateral.

Geometricamente, a AF1 torna-se mais delgada lateralmente até o seu completo desaparecimento. Tal associação faz contatos de base e lateralmente com os xistos do Supergrupo Rio das Velhas. O contato de base dá-se por meio de uma superfície de discordância erosiva e angular, ao passo que os contatos laterais mostram-se cisalhados. O contato de topo com a AF2 é gradacional e, por vezes, brusco, localmente separado por discordância erosiva.

A distribuição espacial restrita, e a escassez de estruturas primárias sugerem que a AF1 é relacionada a fluxos de detritos formados próximos a declives abruptos (Lowe,

Tabela 2. Descrição e interpretação das associações de fácies da Formação Moeda na Serra da Calçada.

\begin{tabular}{|c|c|c|c|}
\hline $\begin{array}{l}\text { Associação } \\
\text { de fácies }\end{array}$ & Descrição & & Interpretação \\
\hline $\begin{array}{l}\text { AF1 } \\
\text { Gms, Gm e } \\
\text { Fsc }\end{array}$ & $\begin{array}{c}\text { Conglomerados polimíticos com matriz } \\
\text { argilosa a arenosa em direção ao topo } \\
\text { (maciços ou gradação incipiente), } \\
\text { descontínuos lateralmente. Clastos } \\
\text { angulosos a arredondados de quartzo, } \\
\text { filitos, xistos e chert. Raras lentes de } \\
\text { pelitos intercaladas. }\end{array}$ & $\begin{array}{l}\text { Sistema de leques } \\
\text { aluviais com rios } \\
\text { entrelaçados } \\
\text { associados. }\end{array}$ & $\begin{array}{l}\text { Fluxo de sedimentos por gravidade } \\
\text { em área proximal de leques aluviais } \\
\text { evoluindo para a porção distal com } \\
\text { rios entrelaçados associados. A } \\
\text { variação faciológica pelítica indica } \\
\text { efeitos tectônicos atuantes ou sistemas } \\
\text { climáticos diversificados. }\end{array}$ \\
\hline $\begin{array}{l}\text { AF2 } \\
\text { Gm, Sh, St, } \\
\text { Sp e FI }\end{array}$ & $\begin{array}{l}\text { Conglomerado polimíticos interdigitados } \\
\text { com arenitos imaturos, maciços e com } \\
\text { estratificação cruzada acanalada e planar, } \\
\text { lentes de conglomerado maciças e } \\
\text { intercalações pelíticas. }\end{array}$ & $\begin{array}{l}\text { Sistema de } \\
\text { planície fluvial } \\
\text { entrelaçada. }\end{array}$ & $\begin{array}{c}\text { Depósito aluvial /fluvial. Ambiente } \\
\text { deposicional em planície fluvial } \\
\text { entrelaçada. Com registros de acreção à } \\
\text { jusante, canais, planícies de inundação e } \\
\text { pequenas barras. }\end{array}$ \\
\hline $\begin{array}{l}\text { AF3 } \\
\text { Fl, Sh }\end{array}$ & $\begin{array}{l}\text { Intercalações de arenitos finos a muito finos, } \\
\text { siltitos a pelitos com nódulos de oxido de } \\
\text { ferro, laminações e estruturas lenticulares } \\
\text { arenosas (acamamento lenticular). }\end{array}$ & $\begin{array}{l}\text { Sistema marinho } \\
\text { raso e/ou lacustre } \\
\text { associado. }\end{array}$ & $\begin{array}{c}\text { Entrada de sedimentos finos no } \\
\text { ambiente aluvial. Acamamento indicando } \\
\text { flutuações de suprimento sedimentar e } \\
\text { atividade de correntes ou ondas, fácies } \\
\text { típicas de planície de maré. Sistema } \\
\text { lacustre ou marinho raso, com frente } \\
\text { deltáica associada. }\end{array}$ \\
\hline $\begin{array}{l}\text { AF4 } \\
\text { Gm, Gp, Gt, } \\
\text { Fl, Sh, Sp, } \\
\text { St. }\end{array}$ & $\begin{array}{c}\text { Lentes de conglomerados polimíticos } \\
\text { com estratificações cruzadas acanalada } \\
\text { e planar, arenitos maciços, com } \\
\text { estratificações cruzada acanalada e planar, } \\
\text { siltitos estratificado. }\end{array}$ & $\begin{array}{l}\text { Sistema de } \\
\text { planície fluvial } \\
\text { entrelaçada. }\end{array}$ & $\begin{array}{c}\text { Depósitos fluviais com registros de } \\
\text { canais, planícies de inundação e barras } \\
\text { conglomeráticas. Ambiente fluvial } \\
\text { entrelaçado. }\end{array}$ \\
\hline $\begin{array}{l}\text { AF5 } \\
\text { Sh, St, Fl, } \\
\text { Fsc }\end{array}$ & $\begin{array}{c}\text { Arenitos estratificados, laminados e } \\
\text { maciços com granulometria fina a média, } \\
\text { enriquecidos em argilominerais. Em direção } \\
\text { ao topo gradação normal e intercalações } \\
\text { mais frequentes de pelitos. Discordância } \\
\text { onlap com AF4. }\end{array}$ & $\begin{array}{l}\text { Sistema } \\
\text { marinho raso. }\end{array}$ & $\begin{array}{c}\text { Ambiente litorâneo, com planície de maré } \\
\text { e transgressão marinha associada. }\end{array}$ \\
\hline
\end{tabular}

Fonte: adaptado de Walker e James (1992), Tucker (2014), Miall (2016). 
1982; Nemec e Steel, 1984). A grande quantidade de material arenítico e baixa proporção de lama sugere fluxo subaéreo (Lowe, 1982) com transporte por canais fluviais associados, indicando, portanto, condições subaquosas durante a fase final de deposição (Haughton et al., 2009). Tal associação de fácies é interpretada como representante de um sistema deposicional de leques aluvias dominados por fluxos de detritos com rios entrelaçados associados, considerando que canais entrelaçados podem formar-se no interior dos leques (Boothroyd e Nummedal, 1978).

\section{Associação de fácies 2 (AF2): \\ sistema de planície fluvial entrelaçada}

Esta associação é contínua em toda a área (Figura 3), ocorrendo sobreposta a AF1 em contato erosivo ou gradacional. Sua espessura é variada, podendo atingir de 130 até $260 \mathrm{~m}$. Tem grau de maturidade composicional/textural superior ao da AF1, compreendendo uma combinação das fácies sedimentares $\mathrm{Gm}, \mathrm{Sh}, \mathrm{St}, \mathrm{Sp}$ e Fl, sendo a Sh a predominante e a Fl de ocorrência mais restrita.

A AF2 tem porção basal com níveis conglomeráticos polimíticos maciços texturalmente mal selecionados. A sua matriz é composta de grãos de areia grossa e os clastos são de quartzo fumê, quartzo leitoso e, em menor quantidade, filitos e xistos. As espessuras destes níveis nesta $\mathrm{AF}$ variam de 4 a $14 \mathrm{~m}$. Nos níveis arenosos, predominantes em direção ao topo, ocorrem, interdigitados ou intercalados, lentes de conglomerado com espessuras de $1 \mathrm{a} 2 \mathrm{~m}$. Estes são semelhantes aos níveis basais, mas com moderada seleção textural e essencialmente compostos de clastos de variedades de quartzo. Lentes pelíticas com laminações de siltito e arenitos finos foram notadas em alguns levantamentos, com espessuras variando de 0,8 a $3,4 \mathrm{~m}$. Ocorrem desde a porção centro-norte da Serra da Calçada até a sua terminação meridional, na qual são mais frequentes. Nos arenitos estratificados foram medidas paleocorrentes indicando direções de NW para SE na porção centro-norte (Perfil Mirante dos Cristais) e NNE para SSW na porção centro-sul (Perfil Forte Brumadinho). Os contatos entre as fácies constituintes são, na maioria das vezes, gradacional e localmente erosivo.

De modo geral, a AF 2 tem inicialmente gradação inversa ascendente na base que muda para gradação normal em direção ao topo nos pacotes superiores. Na porção centro-sul (Perfil Forte Brumadinho), essa relação é sempre gradacional normal ascendente (Figura 8), talvez por conta de um período constante de afogamento da bacia nessa porção (Figura 8).

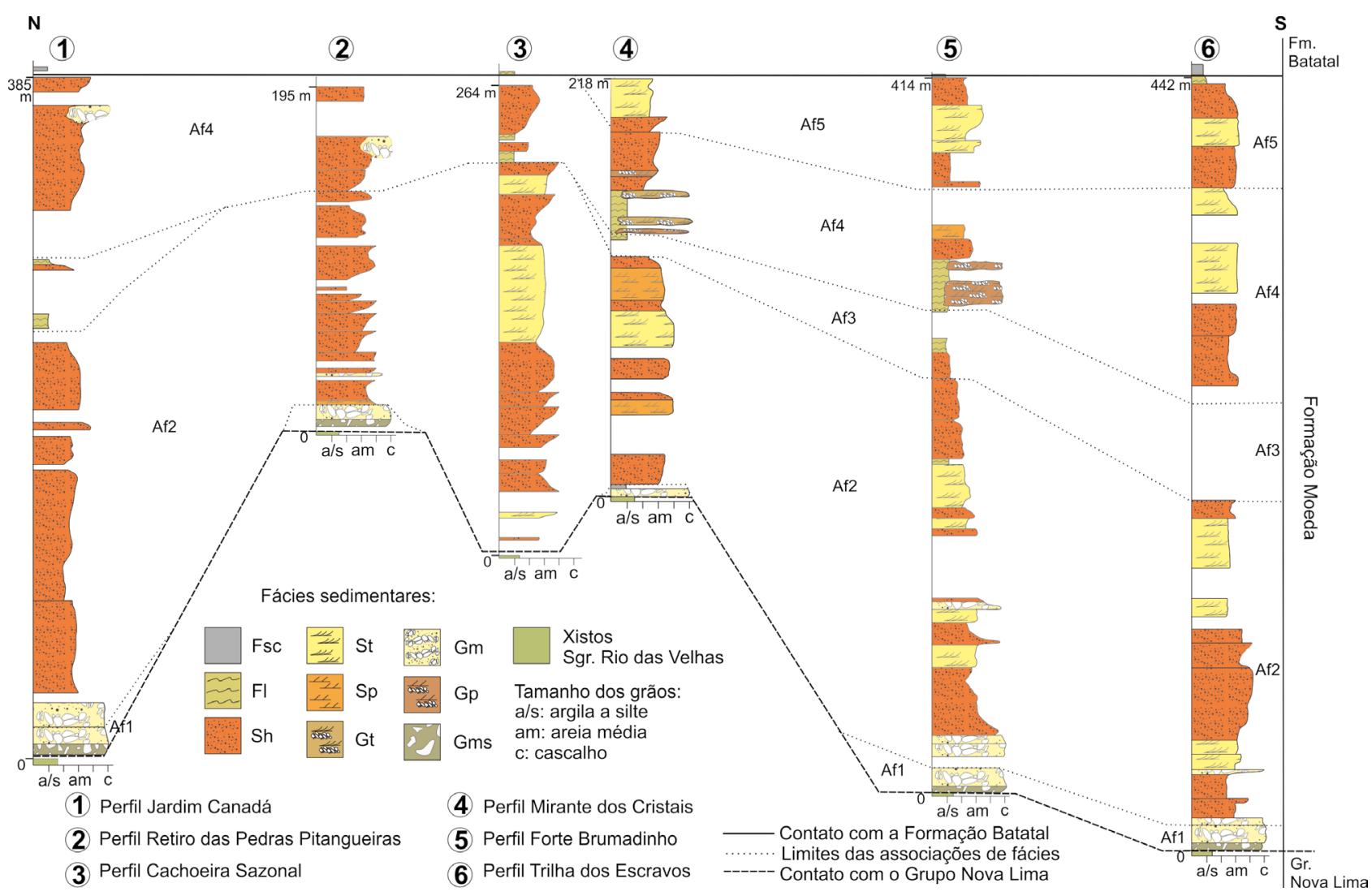

Figura 8. Seções da Formação Moeda integradas e subdivididas em associações de litofácies. Empregou-se como datum estratigráfico a base da Formação Batatal. 
Tal associação de fácies tem elementos típicos de depósitos fluviais, apresentando macroformas como canais, sand bed form, acreção a jusante, planícies de inundação e barras cascalhosas (Miall, 1978, 1996). Os níveis de material mais fino (pelitos, siltitos e arenitos finos) podem ser interpretados como registros de pequenas planícies de inundação; as lentes conglomeráticas são interpretadas como depósitos de channel lag ou barras longitudinais; e os níveis conglomeráticos basais indicam porções distais de leques aluviais. Utilizando-se os conjuntos de feições sintetizadas por Tucker (2014), a AF 2 pode ser deduzida como uma planície fluvial entrelaçada, cuja porção basal caracterizaria uma transição entre sistemas de leques aluviais.

\section{Associação de fácies 3 (AF3):}

sistema lacustre ou marinho raso

A associação AF3 é descontínua, recobrindo a $\mathrm{AF} 2$ nas porções sul e norte da Serra da Calçada (Figuras 3 e 8). Tal associação é composta principalmente da litofácies $\mathrm{Fl}$, que ocorre localmente em associação com a Sh e St, constituída, portanto, de siltitos com níveis de pelitos e arenitos diversificados. O contato, tanto de topo quanto de base com as associações limítrofes, são, na maioria dos casos, gradacionais.

$\mathrm{Na}$ Serra da Calçada, a espessura desse conjunto é variada. No centro-norte da área os afloramentos não ocorrem ou são muito delgados, com $12 \mathrm{~m}$ aproximadamente. As camadas tonam-se mais espessas tanto para norte quanto para sul, onde chegam a 34 e $68 \mathrm{~m}$, respectivamente. A AF3 é facilmente delimitada nas imagens aéreas, sempre associada às porções mais aplainadas no topo da Serra da Calçada com padrão textural liso. A geometria geral do conjunto é lenticular e cuneiforme nas porções norte e sul, respectivamente, mantendo as maiores dimensões na direção meridional

Tal associação engloba os litotipos mais finos da Formação Moeda. Arenitos com granulação grossa são raros e, quando ocorrem, são texturalmente mal selecionados, predominando as areias finas. Esses litotipos podem apresentar acamamento lenticular, estratos cruzados e marcas de ondulações de pequeno porte. Os níveis areníticos (fácies Sh e St) estão frequentemente em geometria lenticular centimétrica ou em camadas tabulares com até $3 \mathrm{~m}$, limitadas por níveis pelíticos milimétricos a centimétricos. Nódulos de óxido de ferro ocorrem dispersos na matriz dos siltitos, tendo auréola de alteração avermelhada e atingindo diâmetros de até $5 \mathrm{~cm}$.

A abundância de sedimentos pelíticos e siltosos em associação com escassas areias estratificadas permite interpretar esse conjunto de fácies como uma entrada de sedimentos finos no ambiente fluvial. O acamamento lenticular indica flutuações de suprimento sedimentar e atividade de correntes ou ondas, fácies típicas de planície de maré. Nódulos de pirita podem sem formados durante a diagênese de sedimentos lamosos marinhos ricos em matéria orgânica
(Tucker, 2014), justificando a sua ocorrência, que, atualmente expostos, ocorrem oxidados. Portanto, esse sistema pode ser interpretado como marinho raso, com planície de maré, lagunas e frentes deltaicas associadas.

Associação de fácies 4 (AF4): sistema de planície fluvial entrelaçada

A quarta associação, $\mathrm{AF} 4$, assim como a AF2, é uma sequência com expressiva distribuição areal, tendo ampla extensão lateral. Na Serra da Calçada, suas espessuras variam de 43 a $83 \mathrm{~m}$ nas porções centro-norte e sul, respectivamente. A AF4 é essencialmente arenítica, englobando principalmente a fácies Sh, com ocorrência subordinada da Sp no topo e das conglomeráticas Gm e Gt associadas aos pelitos e siltitos Fl na base.

Apresenta geometria tabular, com contatos basais gradacionais ou abruptos com a AF3. Na porção basal, os níveis conglomeráticos estão em forma de lentes em meio a uma camada siltosa (Figura 8), característica comum na Serra da Calçada. Os conglomerados são polimíticos em corpos lenticulares, tendo níveis arenosos com estratificação cruzada acanalada e/ou planar e matriz com granulometria média a grossa (Figura 4E). Os clastos têm aproximadamente $8 \mathrm{~cm}$ de diâmetro, podendo atingir até $30 \mathrm{~cm}$, são constituídos de quartzo de veio (fumê, leitoso, cristalino) e, menos frequentemente, quartzito e filitos. Na porção norte tal associação apresenta-se texturalmente mais grosseira e mal selecionada, e os níveis siltosos com lentes conglomeráticas tornam-se mais frequentes na porção centro-sul da Serra da Calçada (Figura 8).

Em direção ao topo dessa associação ocorrem arenitos de granulometria areia fina a grossa, portando estratificações cruzadas acanaladas e planares; localmente, medidas de paleocorrentes indicam sentido para WSW. Os pacotes possuem geometria tabular a lenticular. De maneira geral, os sedimentos vão tornando-se texturalmente mais maturos e enriquecidos em argilo-minerais, prevalecendo uma granulometria fina a média, com diminuição no aporte das estratificações (Figura 5A). Nessa porção, o contato com a AF5 é gradacional, característica que se torna cada vez mais frequente em direção ao sul da Serra da Calçada.

Tal associação de fácies também pode ser interpretada como uma planície fluvial entrelaçada, assemelhando-se à AF2. Ocorrem registros de canais e planícies de inundação. As lentes de conglomerados indicam registros de barras cascalhosas do sistema fluvial entrelaçado.

\section{Associação de fácies 5 (AF5): sistema marinho raso}

Esta associação está entre as de ocorrência mais restrita e menor distribuição areal na região estudada (Figura 3). As espessuras variam de 27 a $105 \mathrm{~m}$, as porções mais delgadas 
localizam-se na região central e as mais espessas, ao sul da Serra da Calçada (Figura 8). Caracteriza-se pela composição arenítica e pelítica, fácies Sh, St, Fl, Fsc com geometria tabular gradando para as rochas pelíticas da Formação Batatal. Em ampla escala, tal unidade encobre gradualmente a AF4, indo de encontro a esta associação de sul para norte, caracterizando uma relação estratigráfica onlap.

Nesse conjunto prevalecem, na base, arenitos estratificados, laminados e maciços com granulometria fina a média (fácies St e Sh). Estes são enriquecidos em argilo-minerais, predominando uma gradação normal em direção ao topo. Tais fácies areníticas ocorrem em níveis alternados com granulometria fina e grossa, frequentemente com grãos de quartzo bem selecionados e subarrendados. Em direção às camadas superiores desta associação, a proporção de material argiloso (finos) aumenta em relação à fração areia, predominando, no topo, unidades pelíticas de espessuras centimétricas a decimétricas com raros níveis siltosos. Os sedimentos da AF5 são texturalmente maturos e bem selecionados, com ocorrência escassa de grãos de quartzo fumê e óxidos, componentes detríticos muito frequentes nas unidades anteriores.

A boa seleção textural e a associação com sedimentos finos revelam a entrada de elementos característicos de ambientes litorâneos na região, com planície de maré e transgressão marinha associada. Na base, observa-se a influência continental de um ambiente costeiro, gradando em direção ao topo para essencialmente marinho raso, até a entrada definitiva dos pelitos da Formação Batatal.

\section{EVOLUÇÃO TECTONO-SEDIMENTAR E CONTEXTO PALEOGEOGRÁFICO}

Correlacionando os levantamentos estratigráficos realizados neste trabalho com a subdivisão da Formação Moeda proposta por Wallace (1958) e Villaça (1981), as associações de fácies 1 e 2 (AF1 e AF2) inserem-se no membro 1. $\mathrm{O}$ membro 2 engloba, na totalidade, a associação de fácies 3 (AF3), em que predominam os litotipos mais finos. E o membro 3 compreende as associações de fácies 4 e 5 .

As associações de fácies são grupos de fácies geneticamente relacionados entre si que têm um significado paleoambiental (Collinson et al., 2006), possibilitando a interpretação dos sistemas deposicionais. Na análise de bacias, a sucessão dessas associações de fácies materializam as principais mudanças que operaram durante a deposição de uma unidade litoestratigráfica (Walker e James, 1992). Dessa forma, a interpretação desses cinco conjuntos mapeáveis, aqui propostos, para a Formação Moeda na área em questão auxilia na reconstituição da evolução tectono-sedimentar dessa unidade.

O mapeamento geológico de detalhe revelou a distribuição areal das associações e evidenciou falhas direcionais com componentes normais orientadas segundo ENE e WNW. Tais falhas destacam-se nas imagens de radar 1:25.000 do Web Map Service OGC (WMP) como lineamentos expressivos e foram descritas em mapeamentos anteriores (Baltazar et al., 2005).

A seção restaurada da Serra da Calçada demonstrou uma configuração em altos e baixos estruturais do embasamento diretamente relacionado com as falhas e fraturas mapeadas. Tais estruturas, que atingem a superfície de contato do Supergrupo Rio das Velhas com a Formação Moeda, revelam-se de natureza distensiva, diretamente correlacionadas com a ocorrência da AF1 e influenciam a espessura e a geometria das associações de fácies, demonstrando, assim, uma gênese sin-deposicional relacionada a falhas de crescimento da bacia (Figura 3).

Ao longo da sedimentação dos litotipos da Formação Moeda, desenvolveu-se um alto estrutural do embasamento na porção centro-norte da área (Figura 9). Durante a deposição da $\mathrm{AF} 2$, tal porção prevaleceu abaixo do nível de base e, portanto, a região recebeu sedimentos ao longo de toda a sua extensão. Na transição para $\mathrm{AF} 3$ e base da $\mathrm{AF} 4$, a região é ativada tectonicamente e atua como um obstáculo para a deposição desses litotipos (Figura 9).

Nos estágios inicias de deposição, as falhas mapeadas foram geradas e reativadas influenciando o nível de base da bacia. Esse cenário muda na fase final, em que a entrada de um sistema litorâneo (deposição da AF5) ocorre por transgressão marinha como consequência de uma variação eustática evidenciada pela discordância onlap realçada na seção restaurada (Figura 9). Nesse período, as porções mais proximais, localizadas ao norte do alto estrutural, prevalecem sob influência de sistemas continentais fluviais (topo da AF4, Figura 9)

Os levantamentos acerca da natureza dos sedimentos (composição, textura, estruturas sedimentares, geometria, relações de contato e controles tectônicos) foram integrados ao acervo geológico e geocronológico da Formação Moeda. Tais dados conduziram a um modelo paleotectônico e considerações acerca da paleogeografia do estágio inicial de abertura da Bacia Minas.

Segundo Romano et al. (2013) e Dopico et al. (2017), a fase de rifteamento continental que deu origem a Bacia Moeda não foi acompanhada de magmatismo devido a eventos antecedentes de granitogênese enriquecida em potássio $(\sim 2.62 \mathrm{Ga})$, em que a crosta inferior se tornou empobrecida em elementos radiogênicos, o que dificultou sua fusão durante o evento de rifteamento. Portanto, a evolução paleotectônica da Bacia Minas começou com uma sedimentação sin-rifte, sem magmatismo associado, caracterizada por elevação local e erosão, gerando sedimentação aluvial grosseira. Estruturas de pequena escala dentro da bacia afetaram a deposição, criando altos e baixos estruturais locais, que controlaram o transporte de sedimentos e o espaço de 
acomodação e deposição. A interação complexa entre espaço de acomodação, abastecimento e transporte de sedimentos foi determinante para o desenvolvimento da geometria dos litotipos da Formação Moeda.

A deposição da AF1 sugestiona a proximidade de falhas normais ativas que controlaram sua deposição. Inicialmente, foram gerados grábens não conectados que receberam sedimentação a partir de leques aluviais com canais entrelaçados associados, tendo como área-fonte os sistemas de horsts adjacentes (Figura 10A). A configuração do sistema de horsts e grábens gerado no tempo da deposição da AF1 foi determinante para a estruturação posterior da bacia nesta região, controlando a natureza e a geometria das demais associações de fácies.

$\mathrm{O}$ sistema atuante na deposição da AF2 revela grande aporte de sedimentos e descarga altamente variada com leques aluviais proximais na base, e topo evoluindo para planícies fluviais entrelaçadas (Figura 10B). As estruturas herdadas da primeira fase de abertura da bacia possivelmente permaneceram ativas, atuando em profundidade e controlando a entrada de sedimentos e o espaço de acomodação, portanto, influenciando na variação de espessura desta unidade. O nível de base da bacia foi controlado principalmente pelos processos tectônicos desse novo pulso extensional.

A AF3 representa regimes de fluxos menos energéticos na bacia, revelando períodos de movimentação tectônica profunda, relativamente mais lenta, gerando bacias rasas e, até mesmo, isoladas na porção centro-norte. Ocorrem ambientes lacustres de extensão e profundidade moderadas. Contudo, avançando para a porção meridional, observa-se aumento gradativo de espessura nesse sentido associado, constantes intercalações entre sedimentos finos e arenosos e estruturas sedimentes de ambientes costeiros. Essas características levam à interpretação de uma predominância de ambiente marinho raso nesse prolongamento da bacia (Tucker, 2014), em que paraconformidade que separa as associações faciológicas 2 e 3 representaria uma superfície onlap (Figura 10C). Tal transgressão marinha foi sincrônica ao desenvolvimento de uma rampa com declividade suave para sul.

As porções individualizadas ao longo da bacia na região da Serra da Calçada foram novamente reativadas durante a deposição da AF4, principalmente na porção setentrional da serra. A instalação de um novo sistema fluvial entrelaçado voltou a operar na Bacia Minas (Figura 10D). A maior quantidade de material fino, o maior grau de arredondamento dos clastos dos conglomerados e a presença de estratificações cruzadas bem desenvolvidas nos arenitos sugerem que esse período de sedimentação possivelmente envolveu maior distanciamento da área fonte dos sedimentos (Della Fávera, 2001).

No estágio que antecedeu a deposição da Formação Batatal pelo menos parte das associações 4 e 5 coexistiu em simultâneo (Figuras 10E e 10F). A primeira predominou na porção norte da área na Serra da Calçada, ao passo que a AF5 se desenvolveu na parcela mais ao sul. O contato entre esses dois conjuntos é gradual e com característica de uma relação estratigráfica onlap, interpretada como um evento discreto de transgressão marinha, em que a AF5 é depositada contra a AF4.

Durante a deposição da AF5, as condições deposicionais foram dominadas por variações eustáticas com pouca ou nenhuma atividade tectônica. A configuração das camadas é, portanto, em virtude da geometria preexistente da bacia e do contexto paleogeográfico (Figura 10E). Esse cenário inicia-se em um dado momento em que a bacia estabiliza-se tectonicamente $e$ as estruturas extensionais tornam-se inativas.

As idades máximas de deposição para a Formação Moeda obtidas por Dopico et al. (2017) são: de 2680 Ma para a unidade I, detentora das ocorrências/mineralizações de ouro, pirita e minerais de urânio detríticos (Minter et al., 1990), e de 2610 Ma para a unidade III. Tais dados mostram um

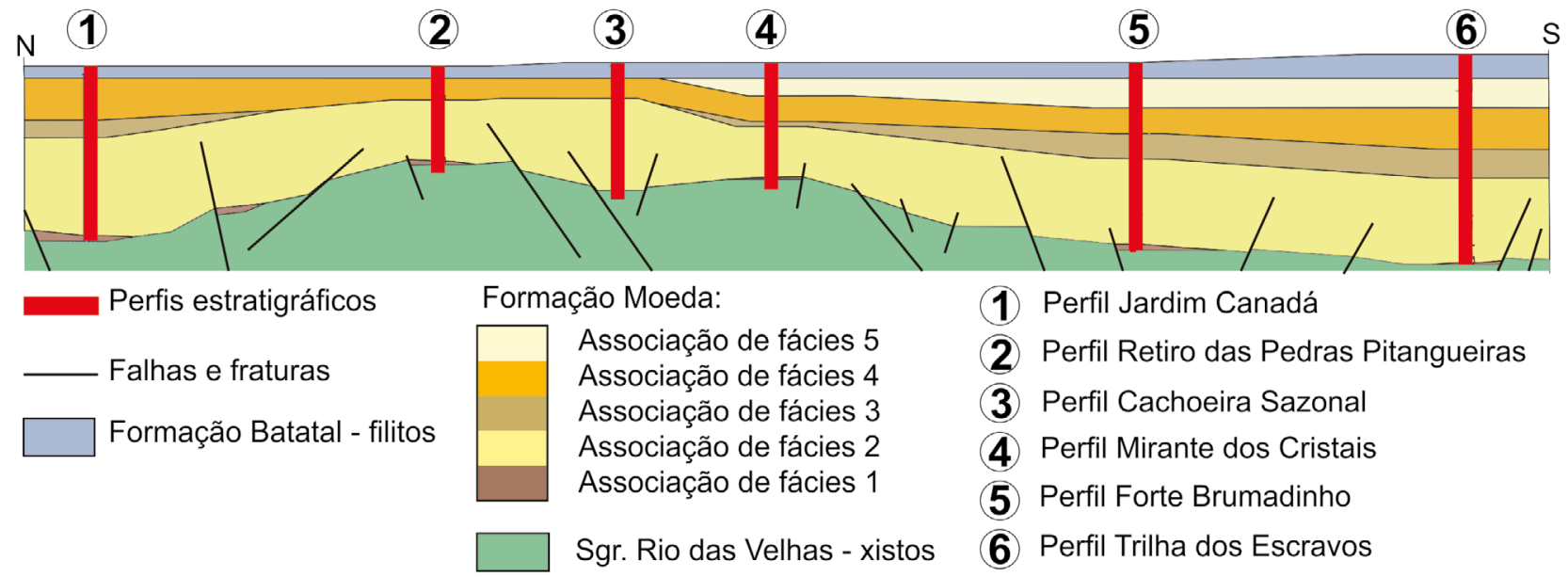

Figura 9. Seção esquemática restaurada do perfil NS na Serra da Calçada. 
rejuvenescimento das fontes em direção ao topo da Formação Moeda, refletindo a evolução da bacia homônima, do estágio rifte para margem passiva. Particularmente na região na Serra da Moeda, a mudança na área fonte dos zircões detríticos ocorreu na porção intermediária da unidade III, representando a transição da $\mathrm{AF} 4$, ainda sob influência da fase rifte, para a AF5, já sob o domínio da margem passiva (Dopico et al., 2017). Esses autores sugerem uma mudança
A

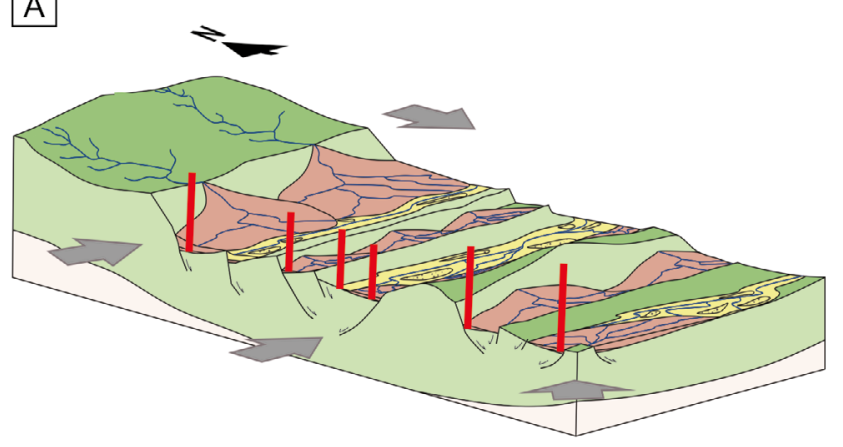

C

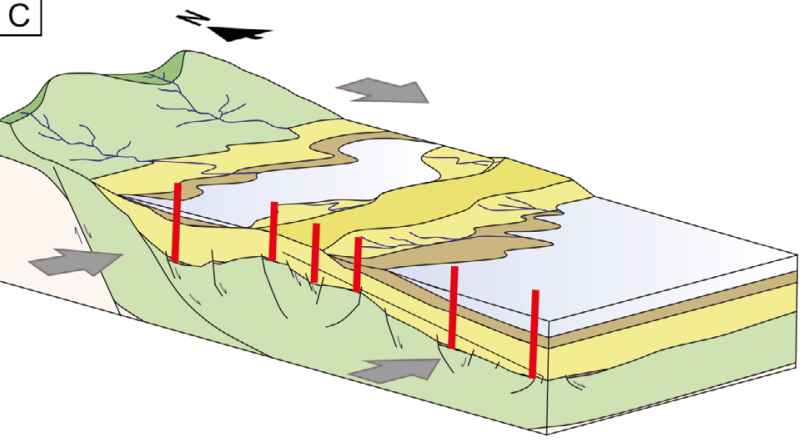

E

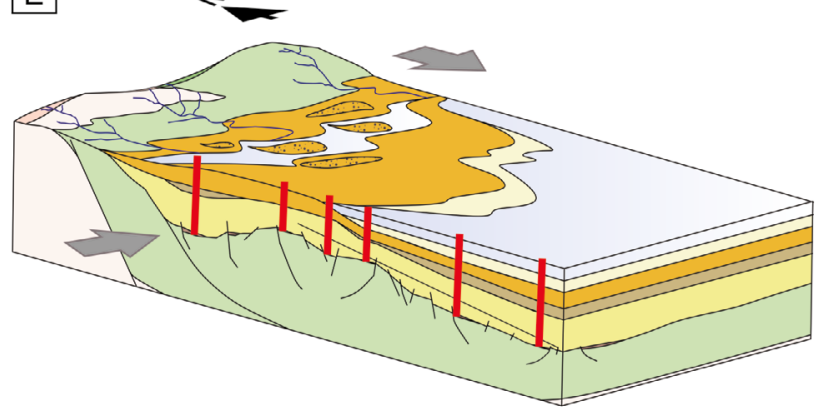

Lâmina de água

Formação Batatal - filitos

Formação Moeda:

Associação de fácies 5

Associação de fácies 4

Associação de fácies 3

Associação de fácies 2

Associação de fácies 1
Embasamento:

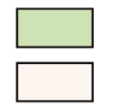

Grupo Nova Lima - xistos

Complexo Bonfim - granitóides

Sentido do movimento

das falhas normais

Sentido principal do fluxo de sedimentos
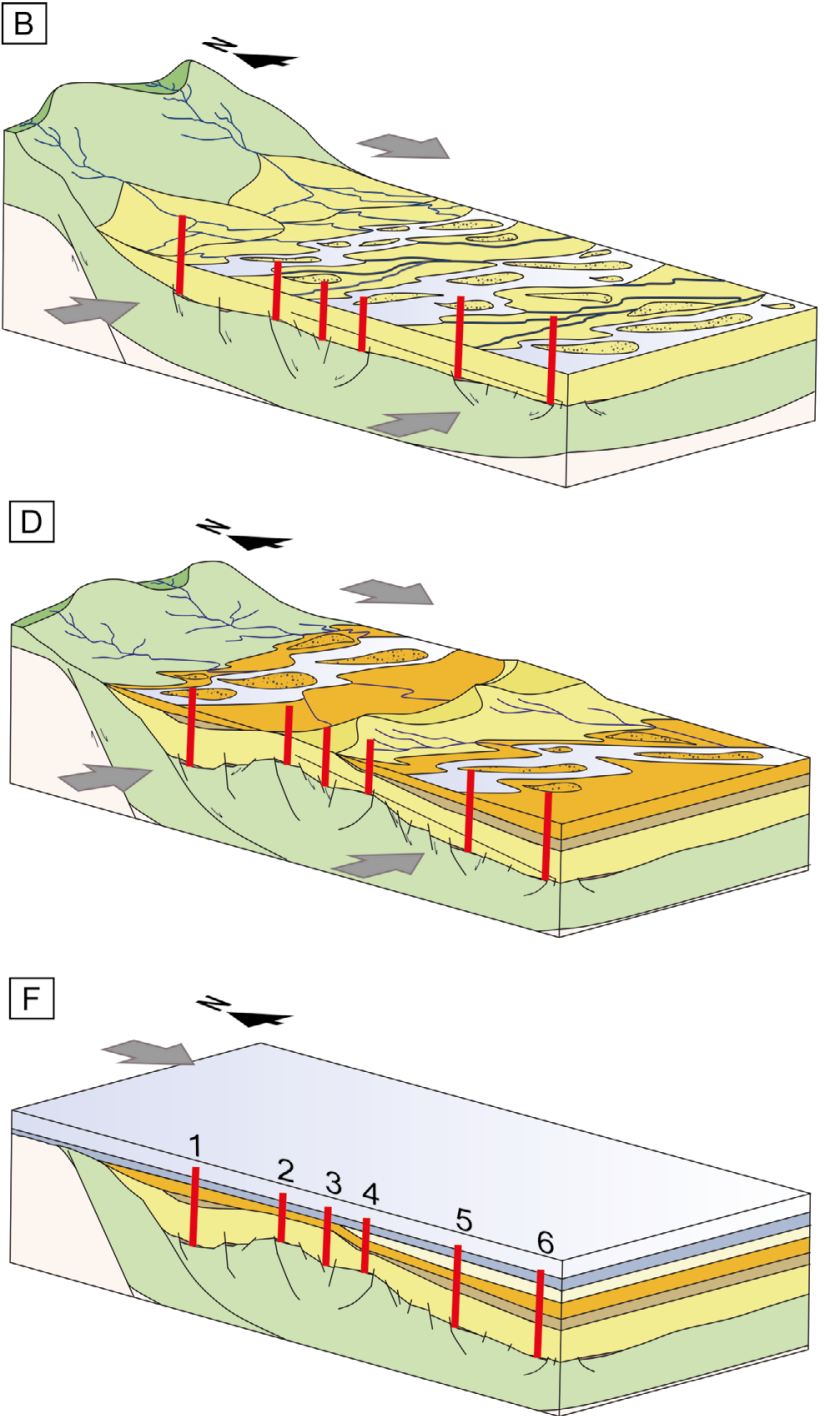

Perfis estratigráficos

1 Perfil Jardim Canadá

2 Perfil Retiro das Pedras

3 Perfil Cachoeira Sazonal

4 Perfil Mirante dos Cristais

5 Perfil Forte Brumadinho

6 Perfil Trilha dos Escravos

Figura 10. Blocos diagramas feitos a partir da seção restaurada esboçando a evolução tectono-sedimentar da Formação Moeda na área de estudo; (A) estágio de deposição da AF1; (B) estágio de deposição da AF2; (C) estágio de deposição da AF 3; (D) estágio de deposição da AF4; (E) estágio de deposição da AF5; (F) estágio de deposição da Formação Batatal. 
no sistema de paleodrenagem ou que uma barreira topográfica foi construída e impediu a fornecimento de outras fontes. De acordo com os dados apresentados, a reativação final de blocos do embasamento durante os estágios finais de deposição da AF4 pode ter promovido a elevação de terrenos dominados granitoides tardios do embasamento. A estruturação final pode ter sido responsável pela exposição e erosão desses terrenos bem como pela geração de barreiras topográficas que controlariam as fontes alimentadoras da bacia (Figura 10).

\section{CONCLUSÕES}

A Formação Moeda, na porção noroeste do QF, revela características da evolução tectono-sedimentar das fases iniciais da Bacia Minas. Por meio da associação de fácies e integração de seções estratigráficas de detalhe apresentada neste estudo, as seguintes conclusões podem ser feitas:

- a Formação Moeda pode ser subdivida em cinco associações de fácies que materializam os principais estágios evolutivos dessa unidade litoestratigráfica. As associações de fácies $\mathrm{AF} 1 \mathrm{e} \mathrm{AF} 2$ representam sistemas de leques aluviais que evoluíram para planícies fluviais entrelaçadas. A AF3 está relacionada a sistemas lacustres associados a marinho raso nas porções distais. Por fim, as associações de fácies AF4 e AF5 representam planícies fluviais entrelaçadas encerradas por uma transgressão marinha no estágio final;

- as associações de fácies $\mathrm{AF} 1, \mathrm{AF} 2, \mathrm{AF} 3$ e a porção basal da AF4 representam o estágio rifte da Bacia Minas. A fase de margem passiva é atingida na transição entre AF4 e $\mathrm{AF} 5$, em que as porções mais profundas estariam para sul/sudeste da área de estudo;

- alguns dos lineamentos estruturais de direção ENE e WNW refletem estruturas tectônicas contemporâneas à sedimentação das cinco associações de fácies. Essas estruturas foram responsáveis pela compartimentação da Bacia Moeda em altos e baixos estruturais locais que controlaram a área fonte e o espaço de acomodação dos sedimentos.

\section{AGRADECIMENTOS}

Os autores agradecem ao Conselho Nacional de Desenvolvimento Científico e Tecnológico (CNPq), a concessão da bolsa de mestrado. Ao projeto PETROBRÁS-FEOP (2015-2018) no 4600479690 (Relações entre Tectônica e Sedimentação em Bacias Rifte e Orogênicas), o apoio e suporte financeiro para a realização desta pesquisa. Aos geólogos Thiago Rolla Nunes e Éden Longo, a ajuda com os trabalhos de campo e as contribuições com as discussões geológicas; ao Departamento de Geologia da Escola de Minas da Universidade Federal de Ouro Preto, por viabilizar este trabalho.

\section{REFERÊNCIAS}

Alkmim, F. F., Marshak, S. (1998). Transamazonian Orogeny in the Southern São Francisco Craton, Minas Gerais, Brazil: Evidence for Paleoproterozoic collision and collapse in the Quadrilátero Ferrífero. Precambrian Research, 90(1-2), 29-58. https://doi.org/10.1016/ S0301-9268(98)00032-1

Alkmim, F. F., Marshak, S., Pedrosa-Soares, A. C., Peres, G. G., Cruz, S. C., Whittington, A. (2006). Kinematic Evolution of the Araçuaí-West Congo orogen in Brazil and Africa: Nutcracker tectonics during the Neoproterozoic assembly of Gondwana. Precambrian Research, 149(1-2), 43-64. https://doi.org/10.1016/j.precamres.2006.06.007

Alkmim, F. F., Martins-Neto, M. A. (2012). Proterozoic firstorder sedimentary sequences of the São Francisco craton, eastern Brazil. Marine and Petroleum Geology, 33(1), 127139. https://doi.org/10.1016/j.marpetgeo.2011.08.011

Babinski, M., Chemale Jr., F., Van Schmus, W. R. (1995). The $\mathrm{Pb} / \mathrm{Pb}$ age of the Minas supergroup carbonate rocks, Quadrilátero Ferrífero, Brazil. Precambrian Research, 72(3-4), 235-245. https://doi. org/10.1016/0301-9268(94)00091-5

Baltazar, O. F., Baars, F. J., Lobato, L. M., Reis L. B., Achtschin, A. B., Berni, G. V., Silveira, V. D. (2005). Mapa Geológico Itabirito na escala 1:50.000. Nota Explicativa. In: L. M. Lobato, O. F. Baltazar, L. B. Reis, A. B. Achtschin, F. J. Baars, M. A. Timbó, G. V. Berni, B. R. V. de Mendonça, D. V. Ferreira (Eds.). Projeto Geologia do Quadrilátero Ferrífero: Integração e Correção Cartográfica em SIG com Nota Explicativa. Belo Horizonte: CODEMIG.

Boothroyd, J. C., Nummedal, D. (1978). Proglacial braided outwash: a model for humid alluvial fan deposits. In: A. D. Miall (Ed.). Fluvial Sedimentology. Canadian Society of Petroleum Geologists, 5. p. 641-668.

Cabral, A. R., Zeh A., Koglin, N., Gomes Jr., A. A. S., Viana, D. J., Lehmann, B. (2012). Dating the Itabira iron formation, Quadrilátero Ferrífero of Minas Gerais, Brazil, at 2.65 $\mathrm{Ga}$ : Depositional U-Pb age of zircon from a metavolcanic layer. Precambrian Research, 204-205, 40-45. https://doi. org/10.1016/j.precamres.2012.02.006 
Canuto, J. R. (2010). Estratigrafia de sequências em bacias sedimentares de diferentes idades e estilos tectônicos. Revista Brasileira de Geociências, 40(4), 537-549. https:// doi.org/10.25249/0375-7536.2010404537549

Collinson, J. D., Mountney, N. P., Thompson, D. B. (2006). Sedimentary structures $\left(3^{\mathrm{a}} \mathrm{ed}\right.$.). Londres: Terra.

Della Fávera, J. C. (2001). Fundamentos da Estratigrafia Moderna. Rio de Janeiro: EdUERJ.

Dopico, C. I. M., Lana, C., Moreira, H. S., Cassino, L. F., Alkmim, F. F. (2017). U-Pb ages and Hf-isotope data of detrital zircons from the late NeoarcheanPaleoproterozoic Minas Basin, SE Brazil. Precambrian Research, 291, 143-161. https://doi.org/10.1016/j. precamres.2017.01.026

Dorr, J. V. N., Gair J. E., Pomerene J. B., Rynearson, G. A. (1957). Revisão da estratigrafia pré-cambriana do Quadrilátero Ferrifero. Rio de Janeiro: DNPM. 31p. (Avulso 81).

Dorr, J. V. N. (1969). Physiographic, stratigraphic and structural development of Quadrilátero Ferrífero, Minas Gerais, Brasil. Geological Survey Professional Paper, 641A, United States Geological Survey (USGS). https://doi. org/10.3133/pp641A

Endo, I., Nalini Jr., H. A. (1992). Geometria e cinemática das estruturas extensionais e compressionais na borda oeste do Sinclinal Moeda, Quadrilátero Ferrífero. Revista da Escola de Minas, 45(1-2), 15-17. http://www.repositorio.ufop.br/ handle/123456789/3754

Farina, F., Albert, C., Martínez Dopico, C., Aguilar Gil, C., Moreira, H., Hippertt, J. P., Cutts, K., Alkmim, F. F., Lana, C. (2016). The Archean-Paleoproterozoic evolution of the Quadrilátero Ferrífero (Brazil): current models and open questions. Journal of South American Earth Sciences, 68, 4-21. https://doi.org/10.1016/j. jsames.2015.10.015

Folk, R. L. (1980). Petrology of sedimentary rocks. Austin: Texas Hemphill's Book Store. http://hdl.handle. net $/ 2152 / 22930$

Hartmann, L. A., Endo, I., Suita, M. T. F., Santos, J. O. S., Frantz, J. C., Carneiro, M. A., McNaughton, N. J., Barley, M. E. (2006). Provenance and age delimitation of Quadrilátero Ferrífero sandstones based on zircon U-Pb isotopes. Journal of South American Earth Sciences, 20(4), 273-285. https:// doi.org/10.1016/j.jsames.2005.07.015
Haughton, P. D. W., Davis, C., McCaffrey, W., Barker, S. P. (2009). Hybrid sediment gravity flow deposits Classification, origin and significance. Marine and Petroleum Geology, 26(10), 1900-1918. https://doi.org/10.1016/j. marpetgeo.2009.02.012

Koglin, N., Zeh A., Cabral, A. R., Gomes Jr., A. A. S., Correa Neto, A. V., Brunetto, W. J., Galbiatti, H. (2014). Depositional age and sediment source of the auriferous Moeda Formation, Quadrilátero Ferrífero of Minas Gerais, Brazil: New constraints from $\mathrm{U}-\mathrm{Pb}-\mathrm{Hf}$ isotopes in zircon and xenotime. Precambian Research, 255, 96-108. https:// doi.org/10.1016/j.precamres.2014.09.010

Lana, C., Alkmim, F. F., Armstrong, R., Scholz, R., Romano, R., Nalini Jr., H. A. (2013). The ancestry and magmatic evolution of Archaean TTG rocks of the Quadrilátero Ferrifero province, southeast Brazil. Precambrian Research, 231, 157-173. https://doi.org/10.1016/j.precamres.2013.03.008

Lowe, D. R. (1982). Sediment gravity flows: II Depositional models with special reference to the deposits of high-density turbidity currents. Journal of Sedimentary Research, 52, 279-297. https://doi. org/10.1306/212F7F31-2B24-11D7-8648000102C1865D

Machado, N., Schrank, A., Noce, C. M., Gauthier, G. (1996). Ages of detrital zircon from Archean-Paleoproterozoic sequences: implications for greenstone belt setting and evolution of a transamazonian foreland basin in Quadrilátero Ferrífero, Southeast Brazil. Earth and Planetary Science Letters, 141(14), 259-276. https://doi.org/10.1016/0012-821X(96)00054-4

Miall, A. D. (1977). A review of the braided river depositional environment. Earth Science Reviews, 13(1), 1-62. https:// doi.org/10.1016/0012-8252(77)90055-1

Miall, A. D. (1978). Lithofacies types and vertical profile models in braided river deposits: a summary. In: A. D. Miall (Ed.), Fluvial Sedimentology (597-604). Canadá: Canadian Society of Petroleum Geologists, 5.

Miall, A. D. (1996). The Geology of Fluvial Deposits: sedimentary facies, basin analysis and petroleum geology. Toronto: Springer Verlag.

Miall, A. D. (2016). Stratigraphy: The Modern Synthesis. Toronto: Springer International Publishing.

Minter, W. E. L., Renger, F. E., Siegers, A. (1990). Early proterozoic gold placers of Moeda Formation within the Gandarela Syncline, Minas Gerais, Brazil. Economic Geology, 85(5), 943-951. https://doi.org/10.2113/gsecongeo.85.5.943 
Nalini Jr., H. A. (1990). Petrografia e geologia estrutural de uma seção ao longo do Sinclinal Moeda e adjacências, Quadrilátero Ferrifero, Minas Gerais. Trabalho de Graduação. Ouro Preto: Departamento de Geologia - UFOP.

Nemec, W., Steel, R. J. (1984). Alluvial and coastal conglomerates: Their significant features and some comments on gravelly mass-flow deposits. In: E. H. Koster, R. J. Steel (Eds.), Sedimentology of Gravels and Conglomerates (1-31). Canadá: Canadian Society of Petroleum Geologists, 10.

Noce, C. M., Pinheiro, S. O., Ladeira, E. A., Franca, C. R., Kattah, S. (1992). A sequência vulcano-sedimentar do Grupo Nova Lima na região de Piedade do Paraopeba, oeste do Quadrilatero Ferrífero, Minas Gerais. Revista Brasileira de Geociências, 22(2), 175-183. https://doi. org/10.25249/0375-7536.1992175183

Nunes, F. S. (2016). Contribuição à estratigrafia e geocronologia U-Pb de zircões detríticos da Formação Moeda (Grupo Caraça, Supergrupo Minas) na Serra do Caraça, Quadrilátero Ferrifero, Minas Gerais. Dissertação (Mestrado). Ouro Preto: Departamento de Geologia - UFOP. http://www.repositorio.ufop.br/handle/123456789/7134

Pettijohn, F., Potter, P., Siever, R. (1987). Sand and sandstone. Nova York: Springer-Verlag.

Pires, F. R. M. (1979). Structural Geology and Stratigraphy at the Junction of the Curral Anticline and the Moeda Syncline, Quadrilátero Ferrifero, Minas Gerais, Brazil. Dissertation (Mestrado). Michigan: Michigan Technological University.

Renger, F. E., Noce, C. M., Romano, A. W., Machado, N. (1994). Evolução sedimentar do Supergrupo Minas: 500 Ma de registro geológico no Quadrilátero Ferrífero, Minas. Geonomos, 2(1), 1-11. https://doi.org/10.18285/ geonomos.v2i1.227
Renger, F. E., Suckau, V. E., Silva, R. M. P. (1993). Sedimentologia e análise de bacia da Formação Moeda, Quadrilátero Ferrífero, Minas Gerais, Brasil. VII Simpósio de Geologia de Minas Gerais, v. 1, p. 41-45. Belo Horizonte: SBG.

Romano, R., Lana, C., Alkmim, F. F., Stevens, G., Armnstrong, R. (2013). Stabilization of the southern portion of the Sao Francisco craton, SE Brazil, through a long-lived period of potassic magmatism. Precambrian Research, 224, 143-159. https://doi.org/10.1016/j.precamres.2012.09.002

Rynearson, G. A., Pomerene, J. B., Dorr, J. V. N. (1954). Contacto basal da Série de Minas na parte ocidental do Quadrilatero Ferrifero, Minas Gerais, Brasil. Brasil: Departamento Nacional de Produção Mineral (DNPM).

Stow, D. A. V. (2006). Sedimentary rocks in the field: a color guide. Londres: Academic Press. https://doi.org/10.1017/ S0016756805261708

Teixeira, W., Sabaté, P., Barbosa, J., Noce, C. M., Carneiro, M.A. (2000). Archean and paleoproterozoic tectonic evolution of the São Francisco Cráton, Brazil. $31^{\circ}$ International Geological Congress, v. 1, p. 101-137. Rio de Janeiro.

Tucker, M. E. (2014). Rochas Sedimentares: guia geológico de campo. Porto Alegre: Bookman.

Villaça, J. N. (1981). Alguns aspectos sedimentares da Formação Moeda. Boletim da Sociedade Brasileira de Geologia, Núcleo Minas Gerais, 2, 93-137.

Walker, R. G., James, N. P. (1992). Facies Models: Response to Sea Level. Geological Association of Canada. https://doi. org/10.1002/gj.3350290317

Wallace, R. M. (1958). The Moeda Formation. Boletim da Sociedade Brasileira de Geologia, 7-2, 59-60. 